\title{
Apoptotic and anti-proliferative effect of guanosine and guanosine derivatives in HuT-78 T lymphoma cells
}

\author{
Erich H. Schneider ${ }^{1}$ • Olga Hofmeister ${ }^{2}$. Solveig Kälble ${ }^{1} \cdot$ Roland Seifert $^{1}$
}

Received: 1 October 2019 / Accepted: 27 March 2020 / Published online: 20 April 2020

(C) The Author(s) 2020

\begin{abstract}
The effects of $100 \mu \mathrm{M}$ of $3^{\prime}, 5^{\prime}$-cGMP, cAMP, cCMP, and cUMP as well as of the corresponding membrane-permeant acetoxymethyl esters on anti-CD3-antibody (OKT3)-induced IL-2 production of HuT-78 cutaneous T cell lymphoma (Sézary lymphoma) cells were analyzed. Only $3^{\prime}, 5^{\prime}$-cGMP significantly reduced IL-2 production. Flow cytometric analysis of apoptotic (propidium iodide/annexin V staining) and anti-proliferative (CFSE staining) effects revealed that $3^{\prime}, 5^{\prime}$-cGMP concentrations $>50 \mu \mathrm{M}$ strongly inhibited proliferation and promoted apoptosis of HuT-78 cells (cultured in the presence of $\alpha \mathrm{CD} 3$ antibody). Similar effects were observed for the positional isomer $2^{\prime}, 3^{\prime}$-cGMP and for $2^{\prime}$,-GMP, $3^{\prime}$-GMP, 5'-GMP, and guanosine. By contrast, guanosine and guanosine-derived nucleotides had no cytotoxic effect on peripheral blood mononuclear cells (PBMCs) or acute lymphocytic leukemia (ALL) xenograft cells. The anti-proliferative and apoptotic effects of guanosine and guanosine-derived compounds on HuT-78 cells were completely eliminated by the nucleoside transport inhibitor NBMPR (S-(4Nitrobenzyl)-6-thioinosine). By contrast, the ecto-phosphodiesterase inhibitor DPSPX (1,3-dipropyl-8-sulfophenylxanthine) and the CD73 ecto-5'-nucleotidase inhibitor AMP-CP (adenosine 5'-( $\alpha, \beta$-methylene)diphosphate) were not protective. We hypothesize that HuT-78 cells metabolize guanosine-derived nucleotides to guanosine by yet unknown mechanisms. Guanosine then enters the cells by an NBMPR-sensitive nucleoside transporter and exerts cytotoxic effects. This transporter may be ENT1 because NBMPR counteracted guanosine cytotoxicity in HuT-78 cells with nanomolar efficacy $\left(\mathrm{IC}_{50}\right.$ of $\left.25-30 \mathrm{nM}\right)$. Future studies should further clarify the mechanism of the observed effects and address the question, whether guanosine or guanosinederived nucleotides may serve as adjuvants in the therapy of cancers that express appropriate nucleoside transporters and are sensitive to established nucleoside-derived cytostatic drugs.
\end{abstract}

Keywords Nucleoside transporters $\cdot$ Guanosine $\cdot$ Apoptosis $\cdot$ Proliferation $\cdot$ Leukemia $\cdot$ T-cells

\section{Abbreviations}

$A L L$

$A M P-C P$
Acute lymphocytic leukemia

Adenosine-5'-( $\alpha, \beta$-methylene)diphos-

phate, a CD73 ectonucleotidase inhibitor

Electronic supplementary material The online version of this article (https://doi.org/10.1007/s00210-020-01864-8) contains supplementary material, which is available to authorized users.

Erich H. Schneider

schneider.erich@mh-hannover.de

1 Institute of Pharmacology, Medical School of Hannover, Carl-Neuberg-Str. 1, 30625 Hannover, Germany

2 Institute of Molecular Toxicology and Pharmacology, Helmholtz Zentrum München-German Research Center for Environmental Health, Ingolstädter Landstrasse 1, 85764 Neuherberg, Germany $2^{\prime}, 3^{\prime}-$ or

3', 5'-cAMP

Annexin

$V-A P C$

$B S A$

cCMP

CEM-ARA-C/8C

CFSE

$2^{\prime}, 3^{\prime}-$ or

3',5'-cGMP

cIMP

cNMP

cNMP-AM

$c U M P$
Adenosine 2', $3^{\prime}$ - or $3^{\prime}, 5^{\prime}$-cyclic monophosphate Allophycocyanin-labeled annexin V

Bovine serum albumin Cytidine 3',5'-cyclic monophosphate Arabinosylcytosine-resistant childhood T acute lymphoblastic leukemia cell line 5(6)-Carboxyfluorescein diacetate $\mathrm{N}$ succinimidyl ester

Guanosine 2',3'- or 3',5'-cyclic monophosphate Inosine 3',5'-cyclic monophosphate Cyclic nucleoside monophosphate Cyclic nucleoside 3',5' monophosphate acetoxymethyl ester Uridine 3',5'-cyclic monophosphate 


\begin{tabular}{|c|c|}
\hline$D P S P X$ & $\begin{array}{l}\text { 1,3-Dipropyl-8-p-sulfophenylxanthine, } \\
\text { an ecto-phosphodiesterase inhibitor }\end{array}$ \\
\hline EDTA & Ethylenediaminetetraacetic acid \\
\hline ELISA & Enzyme-linked immunosorbent assay \\
\hline $3^{\prime}-$ or $5^{\prime}-G M P$ & Guanosine $3^{\prime}$ - or $5^{\prime}$-monophosphate \\
\hline$G P C R$ & G protein-coupled receptor \\
\hline$h C N T 1-3$ & $\begin{array}{l}\text { Human concentrative nucleoside trans- } \\
\text { porters, isoforms 1-3 }\end{array}$ \\
\hline hENT1-4 & $\begin{array}{l}\text { Human equilibrative nucleoside trans- } \\
\text { porters, isoforms } 1-4\end{array}$ \\
\hline HuT-78 cells & $\begin{array}{l}\text { Human } \mathrm{T} \text { cell lymphoma (Sézary lym- } \\
\text { phoma) cell line }\end{array}$ \\
\hline$I L-2$ & Interleukin 2 \\
\hline$M S C$ & Mesenchymal stem cells \\
\hline NB4 cells & Human acute promyelocytic leukemia \\
\hline$N B M P R$ & $\begin{array}{l}6-\mathrm{S}-[(4-\mathrm{Nitropheny}) \text { methyl]-6- } \\
\text { thioinosine, an inhibitor of the equilibra- } \\
\text { tive nucleoside transporter ENT1 }\end{array}$ \\
\hline$N M P$ & Nucleoside monophosphate \\
\hline$O A T$ & Organic anion transporter \\
\hline PBMCs & Peripheral blood mononuclear cells \\
\hline$P B S$ & Phosphate buffered saline \\
\hline$P D E$ & Phosphodiesterase \\
\hline$P I$ & Propidium iodide \\
\hline PMAT & Plasma membrane monoamine transporter \\
\hline $\mathrm{PO}_{4}(\mathrm{AM})_{3}$ & $\begin{array}{l}\text { Phosphate tris(acetoxymethyl)-ester (con- } \\
\text { trol compound for cNMP-AMs) }\end{array}$ \\
\hline$S D$ & Standard deviation \\
\hline$T C R$ & $\mathrm{~T}$ cell receptor \\
\hline
\end{tabular}

\section{Introduction}

Cyclic nucleotides (cNMPs), specifically cAMP and cGMP, are well-established second messengers. Although involvement in intracellular signaling processes is considered the main function of these cNMPs, an increasing body of scientific literature reports on first messenger effects of extracellular cAMP and cGMP. A "cAMP-adenosine pathway" has been repeatedly demonstrated for various cell types (Godinho et al. 2015; Jackson and Raghvendra 2004). 3',5'-cAMP is exported into the extracellular space, followed by enzymatic degradation to adenosine, which in turn activates $G$ protein-coupled receptors (Godinho et al. 2015, Jackson and Raghvendra 2004). A similar pathway seems to exist for $2^{\prime}, 3^{\prime}$-cAMP (Verrier et al. 2011) and for 2',3'-cGMP (Jackson et al. 2019). In addition, several reports suggest that extracellular degradation products of $3^{\prime}, 5^{\prime}$ cGMP exert biological effects in the brain (Albrecht et al. 2013; Saute et al. 2006; Soares et al. 2004). Moreover, the pyrimidine nucleoside uridine activates adenosine receptors (Yilmaz et al. 2008). Thus, the non-canonical cyclic nucleotide cUMP, which is currently discussed as a potential second messenger (Seifert et al. 2015; Berrisch et al. 2017; Ostermeyer et al. 2018; Scharrenbroich et al. 2019), may as well be exported and degraded to biologically active products. Preliminary results suggest that first- and second messenger effects of cyclic nucleotides are highly dependent on the investigated cell type (Schneider et al. 2015).

Here we report on the effects of extra- and intracellular cNMPs and their extracellular degradation products on HuT78 Sézary lymphoma cells in three different functional readouts, namely T cell receptor (TCR)-mediated IL-2 production, apoptosis, and proliferation. Unmodified cNMPs were used to address extracellular effects. Membrane-permeant 3',5'-cNMP acetoxymethyl esters (cNMP-AMs) that release the unmodified 3',5'-cNMPs after cleavage by intracellular esterases were used to investigate intracellular actions. IL-2 production of HuT-78 T cell lymphoma cells (induced with $\alpha \mathrm{CD} 3$ antibody (OKT3) in the absence of $\alpha \mathrm{CD} 28$ ) was significantly inhibited by 3',5'-cGMP, while cGMP-AM was ineffective. Experiments addressing proliferation and apoptosis of HuT-78 cells (cultured in the presence of $\alpha \mathrm{CD} 3$ ) revealed anti-proliferative and pro-apoptotic effects, not only of 3',5'-cGMP but also of $2^{\prime}, 3^{\prime}$-cGMP, 2'-GMP, 3'-GMP, 5'-GMP, and guanosine. The effects of these guanosine-derived compounds depended on the activity of NBMPR (S-(4-Nitrobenzyl)-6-thioinosine)-sensitive nucleoside transporters. By contrast, substances not related to guanosine were ineffective. Our observations may be explained by the hypothesis that HuT-78 cells metabolize 3 ',5'cGMP, 2',3'-cGMP, 2'-GMP, 3'-GMP, and 5'-GMP to guanosine, which enters the cells by an NBMPR-sensitive nucleoside transporter and exerts cytotoxic effects. Further studies are needed to investigate whether guanosine or guanosinederived nucleotides could be used as adjuvants in the chemotherapy of lymphomas expressing appropriate nucleoside transporters.

\section{Materials and methods}

\section{Buffers, reagents, and cell culture media}

CFSE (5(6)-carboxyfluorescein diacetate N-succinimidyl ester; Cat.\# 21888) and propidium iodide solution (Cat.\# P4864) was provided by Sigma Aldrich (Taufkirchen, Germany). Annexin-V-APC (Cat.\# AnxA100) was purchased from MabTag (Frisoythe, Germany). Mouse monoclonal (OKT3) anti-CD3 antibody (Cat.\# SAB4700041) was from Sigma Aldrich (Taufkirchen, Germany). Pacific blue-labeled anti-human CD3 (Cat.\# 300417) was obtained from Biolegend (London, UK). Anti-CD28 antibody (Cat.\# SAB4700135$100 \mu \mathrm{g}$ ) was purchased from Sigma Aldrich (Taufkirchen, Germany). For detection of IL-2, either the Duoset ELISA (Cat.\# DY202) from R\&D Systems (Minneapolis, MN, USA) was used or the ELISA MAX Standard Set for human IL-2 (Cat.\# 431801) from Biolegend (London, UK). 
DPSPX (1,3-dipropyl-8-p-sulfophenylxanthine; Cat.\# A022) and NBMPR (S-(4-nitrobenzyl)-6-thioinosine; Cat.\# N2255) were obtained from Sigma Aldrich (Taufkirchen, Germany). 2',3'-cGMP (Cat.\# G025-50), 3',5'-cGMP (Cat.\# G001-100), 2'-GMP (Cat.\# G022-10), 3'-GMP (Cat.\# G02110 ), and AMP-CP (adenosine- $5^{\prime}-(\alpha, \beta$-methylene)diphosphate, sodium salt; Cat.\# A070) were purchased from Biolog (Bremen, Germany). 5'-GMP disodium salt (Cat.\# G8377) and guanosine (Cat. \# G6752) were provided by Sigma Aldrich (Taufkirchen, Germany).

RPMI 1640 medium (Cat.\# R8758) and fetal calf serum (Cat.\# F7524) were purchased from Sigma Aldrich (Taufkirchen, Germany). L-Glutamine with penicillin/ streptomycin (Gibco \# 10378-016), MEM non-essential amino acids (100x) (Gibco \# 11140-035), sodium pyruvate $100 \mathrm{mM}$ (100x) (Gibco \# 11360-039), and AIMV medium (Gibco \# 12055-091) were obtained from Thermo Fisher Scientific (Waltham, USA). Trypsin/EDTA $0.25 \%$ (Cat.\# T4049) as well as PBS (Dulbecco's phosphate buffered saline, $10 \mathrm{x}$, sterile) were provided by Sigma Aldrich (Taufkirchen, Germany). Biocoll Separating Solution (Cat.\# L6115) for isolation of PBMCs was obtained from Merck, Berlin, Germany.

\section{Cell culture}

HuT-78 cutaneous T lymphoma cells (Sézary lymphoma) were obtained from LGC Standard GmbH (Wesel, Germany) and maintained in RPMI 1640 medium supplemented with $10 \%(\mathrm{v} / \mathrm{v})$ of fetal bovine serum and $2 \mathrm{mM}$ of L-glutamine as well as $100 \mathrm{U} / \mathrm{ml}$ penicillin and $0.1 \mathrm{mg} / \mathrm{ml}$ streptomycin. Moreover, the medium was supplemented with $1 \%(\mathrm{v} / \mathrm{v})$ of MEM non-essential amino acids $(100 \mathrm{x})$ and $1 \mathrm{mM}$ of sodium pyruvate (addition of $100 \mathrm{mM}$ stock solution). The cells were cultured at $37{ }^{\circ} \mathrm{C}$ in the presence of $5 \%$ of $\mathrm{CO}_{2}$. Medium was renewed three times a week by diluting the cells to yield a cell density of $1 \times 10^{5}$ cells on Mondays and Wednesdays and $5 \times 10^{4}$ cells on Fridays.

The acute lymphatic leukemia (ALL) xenografts were obtained from Dr. Beat Bornhauser (Department of Pediatric Oncology, Children's Research Centre, University Children's Hospital Zürich, Zürich, Switzerland). The ALL cells were thawed and seeded in AIMV medium at a density of $2.5 \times 10^{5}$ cells $/ \mathrm{ml}$ in $500 \mu \mathrm{l}$ per well and on a layer of mesenchymal stem cells (MSC). The MSC cells were cultivated in RPMI 1640 medium containing 10\% (v/v) fetal bovine serum, $2 \mathrm{mM}$ L-Glutamine, $100 \mathrm{U} / \mathrm{ml}$ penicillin, and $0.1 \mathrm{mg} / \mathrm{ml}$ streptomycin. MSC cells were split 1:5 twice a week (detachment by $0.25 \%$ Trypsin/EDTA).

Peripheral blood monocytic cells (PBMCs) were obtained from healthy human blood donors. The monocytes were separated by centrifugation with Biocoll separating solution and then seeded on anti-CD3-antibody-coated plates and in RPMI 1640 medium supplemented with $10 \%(\mathrm{v} / \mathrm{v})$ of fetal bovine serum, $2 \mathrm{mM}$ of L-glutamine, $100 \mathrm{U} / \mathrm{ml}$ penicillin, $0.1 \mathrm{mg} / \mathrm{ml}$ streptomycin, and $4 \mu \mathrm{g} / \mathrm{ml}$ anti-CD28 antibody.

\section{IL-2 ELISA}

96-well plates were coated for $24 \mathrm{~h}$ with $50 \mu \mathrm{l}$ of PBS containing $2 \mu \mathrm{g} / \mathrm{ml}$ of $\alpha \mathrm{CD} 3$ antibody (OKT3). On the next day, the plates were washed twice with $1 \times$ PBS and then loaded with $50 \mu \mathrm{l}$ of cell suspension/well $(100,000 \mathrm{HuT}-78$ cells or $1.75 \times 10^{5}$ PBMCs per well) plus $50 \mu l$ media with the corresponding stimuli. After $24 \mathrm{~h}$ of incubation, the plate was centrifuged for $10 \mathrm{~min}$ at $500 \times \mathrm{g}$. After that, supernatant was removed and used for the ELISA experiment. ELISAs were performed according to the manufacturer's instructions (Duoset, Cat. \# DY 202, from R\&D Systems or ELISA MAX Standard Set, Cat. \# 431801, from Biolegend).

\section{Apoptosis assay with HuT-78 cells, ALL-cells, and PBMCs}

HuT-78 cells $\left(1 \times 10^{5}\right.$ cells $\left./ \mathrm{ml}\right)$ were treated for $72 \mathrm{~h}\left(37^{\circ} \mathrm{C}\right.$, $\left.5 \% \mathrm{CO}_{2}\right)$ in $\alpha \mathrm{CD} 3$-antibody-coated 24 -well plates with cNMPs, NMPs, or nucleosides in the presence or absence of inhibitors (AMP-CP, DPSPX, NBMPR). To counteract potential degradation in case of incubation with AMP-CP or DPSPX, $100 \mu \mathrm{M}$ of these inhibitors were not only added at the beginning of the incubation time but also after $24 \mathrm{~h}$ and $48 \mathrm{~h}$. Thus, after $72 \mathrm{~h}$, the samples contained up to $300 \mu \mathrm{M}$ of AMP-CP or DPSPX. On the day of the measurement, the cells were centrifuged $(300 \times g, 4 \mathrm{~min}$, ambient temperature), suspended in $100 \mu \mathrm{l}$ of binding buffer $(10 \mathrm{mM}$ HEPES, $140 \mathrm{mM} \mathrm{NaCl}, 2.5 \mathrm{mM} \mathrm{CaCl}_{2}, \mathrm{pH}$ 7.4) and then incubated with annexin-V-APC for $30 \mathrm{~min}$ in the dark at ambient temperature. After that, each sample was diluted by addition of $200 \mu \mathrm{l}$ of binding buffer. Propidium iodide (PI) solution (final concentration $625 \mathrm{ng} / \mathrm{ml}$ ) was added immediately prior to flow cytometric quantitation of apoptosis, which was performed using a MACSQuant Analyzer (Miltenyi Biotech, Bergisch Gladbach, Germany). Apoptosis was analyzed by generating an annexin-APC/PI dot plot (APC/PI), which allows the discrimination of the following populations: lower left (LL) quadrant (annexin-V-APC- and PI-negative): viable cells; lower right (LR) quadrant (annexin-V-APC-positive, PInegative): early apoptosis; upper right (UR) quadrant (positive for both annexin-V-APC and PI): late apoptosis and upper left (UL) quadrant (positive for PI, negative for annexin-V-APC: necrosis. The data were analyzed with the MACSQuantify software. The degree of apoptosis was defined as percentage of total cells in the LR and UR quadrant ( $=\%$ apoptic cells).

In case of ALL cells, MSC feeder cells were seeded on Fridays on a 24-well plate (pre-coated for $24 \mathrm{~h}$ with $2 \mu \mathrm{g} / \mathrm{ml}$ of $\alpha$-CD3 antibody) at a density of $1 \times 10^{4}$ cells $/ \mathrm{ml}(1 \mathrm{ml}$ per well). Three days later, $500 \mu \mathrm{l}$ of medium were removed and the ALL 
cells were seeded on top of the MSC layer. After incubation with cNMPs, NMPs, nucleosides, and/or NBMPR, the cells were separated from the MSC layer by rinsing with a pipet tip. This led to detachment of the ALL cells, while the MSC cells remained adherent. The ALL cells were centrifuged for $5 \mathrm{~min}$ at $300 \times g$ and then suspended in $100 \mu$ of binding buffer. After that, the cells were incubated with annexin-V-APC for $15 \mathrm{~min}$, followed by an additional incubation step with Pacific Blue antihuman CD3 antibody for $15 \mathrm{~min}$ in the dark at ambient temperature. Cells were washed at $300 \times \mathrm{g}$ for $5 \mathrm{~min}$ and then diluted in $300 \mu \mathrm{l}$ of binding buffer. Apoptosis was determined as described above after addition of PI.

PBMCs were seeded at a density of $1.75 \times 10^{5}$ cells per $\mathrm{ml}$ in $1 \mathrm{ml}$ per well on an anti-CD3 antibody-coated 24-well plate with medium containing anti-CD28 antibody. Flow cytometric analysis of apoptosis was performed using the Annexin V/PI method as described above. Similar to the procedure used for the ALL cells, the PBMCs were also stained with Pacific blue-labeled anti-human CD3, and only the cells with the highest fluorescence were gated for flow cytometric analysis of apoptosis.

\section{HuT-78 cell proliferation assay}

An appropriate number of cells was centrifuged $(300 \times g$, $4 \mathrm{~min}$ ) and resuspended in a minimum of $1 \mathrm{ml}$ of PBS with $0.1 \%$ of bovine serum albumin (BSA), yielding a density of $6.7 \times 10^{6}$ cells $/ \mathrm{ml}$. After that, an appropriate volume of a $250 \mu \mathrm{M}$ of CFSE (carboxyfluorescein succinimidyl ester) stock solution was added to yield a final CFSE concentration of $250 \mathrm{nM}$. The samples were incubated for $10 \mathrm{~min}$ at $37^{\circ} \mathrm{C}$, followed by centrifugation $(300 \times g, 4 \mathrm{~min})$ and resuspension in medium to yield a density of $1 \times 10^{5}$ cells $/ \mathrm{ml}$. This suspension was seeded in an $\alpha \mathrm{CD} 3$-antibody-coated 24 -well plate ( $1 \mathrm{ml} /$ well) and incubated for $72 \mathrm{~h}\left(37{ }^{\circ} \mathrm{C}, 5 \% \mathrm{CO}_{2}\right)$ with cNMPs, NMPs, or nucleosides in the presence or absence of inhibitors (AMP-CP, DPSPX, NBMPR). To counteract potential degradation in case of incubation with AMP-CP or DPSPX, $100 \mu \mathrm{M}$ of these inhibitors were not only added at the beginning of the incubation time but also after $24 \mathrm{~h}$ and $48 \mathrm{~h}$. Thus, after $72 \mathrm{~h}$, the samples contained up to $300 \mu \mathrm{M}$ of AMP-CP or DPSPX. On the day of the measurement, the content of each well $(1 \mathrm{ml})$ was centrifuged $(300 \times g, 4 \mathrm{~min})$ and resuspended in $1 \mathrm{ml}$ of FACS buffer. Proliferation was analyzed by flow cytometric quantitation of residual cellbound CFSE fluorescence using a MACSQuant Analyzer (Miltenyi Biotech, Bergisch Gladbach, Germany).

\section{Statistics and data analysis}

Statistical analysis of the data and generation of diagrams was performed with GraphPad Prism 6.07 (GraphPad Software
Inc., San Diego, CA, USA). The statistical tests are detailed in the figure legends. All data are provided as means \pm SD.

\section{Results}

\section{Effect of cyclic nucleotides on anti-CD3 antibody-induced IL-2 production of HuT-78 lymphoma cells}

The effect of $100 \mu \mathrm{M}$ of the purine cNMPs $3^{\prime}, 5^{\prime}$-cAMP, $3^{\prime}, 5^{\prime}$ cGMP, and $3^{\prime}, 5^{\prime}$-cIMP as well as of the pyrimidine cNMPs 3',5'-cUMP and 3',5'-cCMP on $\alpha \mathrm{CD} 3$-antibody-induced IL-2 production of HuT-78 lymphoma cells was analyzed by ELISA. Additionally, the corresponding membranepermeable acetoxymethyl ester analogues (cNMP-AMs) were tested. For unknown reasons, anti-CD3 antibody-induced IL-2 production of HuT-78 cells showed high interexperimental variability, although the conditions were kept essentially the same in all experiments. Thus, the experiments with almost no stimulation of IL2 production were excluded from analysis. The data from the experiments with high IL2 production, however, clearly differentiate between extra- and intracellular effects of the purine cNMPs. IL-2 release was not affected by unmodified cAMP (Fig. 1a) but significantly enhanced by cAMP-AM (Fig. 1b). By contrast, IL-2 production was significantly reduced by unmodified cGMP (Fig. 1a) but was not modulated by the structurally closely related cIMP (Fig. 1a) and also not by cGMP-AM (Fig. 1b). The unmodified pyrimidine cyclic nucleotides cCMP and cUMP (Fig. 1a) as well as their AM derivatives (Fig. 1b) were ineffective.

\section{Anti-proliferative and apoptotic effects of $3^{\prime}, 5^{\prime}-$ and 2',3'-cGMP and their potential metabolic products on HuT-78 lymphoma cells}

To investigate whether the inhibitory effect of extracellular $3^{\prime}, 5^{\prime}$-cGMP on IL-2 release is associated with a reduction of HuT-78 cell proliferation and/or viability, the influence of $3^{\prime}, 5^{\prime}$ cGMP on proliferation and apoptosis of HuT-78 cells was analyzed in a concentration range from 10 to $200 \mu \mathrm{M}$. The experiments were performed in the presence of $\alpha \mathrm{CD} 3$ antibody and with an incubation time of $72 \mathrm{~h}$. At baseline, only about $5 \%$ of the HuT-78 cells were apoptotic $(5.1 \pm 1.8 \% ; n=8$ independent experiments; mean $\pm \mathrm{SD}$ ). However, this proportion was significantly raised to $17.7 \pm 2.2 \%$ and to $21.8 \pm 0.6 \%$ in the presence of $100 \mu \mathrm{M}$ and $200 \mu \mathrm{M}$ of $3^{\prime}, 5^{\prime}$-cGMP, respectively (Fig. 2a). Representative flow cytometric raw data (scattergrams) are depicted in the supplemental information to illustrate the baseline signal (Suppl. Fig. 1a) and the apoptosis in the presence of $100 \mu \mathrm{M}$ of 3',5'-cGMP (Suppl. Fig. 1b). Interestingly, a similar pro-apoptotic effect (significant at 


\section{a 3',5'-cNMP effects on $\alpha$ CD3-induced IL-2 production of HuT-78 cells}

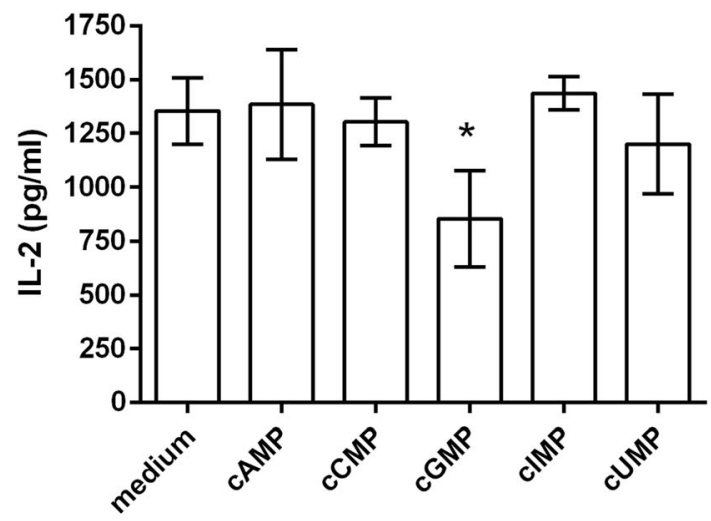

Fig. 1 Effect of unmodified cNMPs and of membrane-permeant cNMPAM esters on $\alpha \mathrm{CD} 3$-antibody-induced IL-2 production of HuT-78 lymphoma cells. Cells were incubated for $24 \mathrm{~h}$ in $\alpha \mathrm{CD} 3$-antibody-coated plates with $100 \mu \mathrm{M}$ of cNMPs (a) or $100 \mu \mathrm{M}$ of cNMP-AMs (b) The "DMSO" and the " $\mathrm{PO}_{4}(\mathrm{AM})_{3}$ " bars represent controls for the DMSO

$100 \mu \mathrm{M}$ and $200 \mu \mathrm{M}$ ) was also found with the structurally closely related positional isomer 2',3'-cGMP (Fig. 2b).

We hypothesized that the effects of $3^{\prime}, 5^{\prime}$-cGMP and 2',3'cGMP on HuT-78 cell apoptosis could be due to common

\section{b 3',5'-cNMP-AM effects on $\alpha$ CD3-induced IL-2 production of HuT-78 cells}

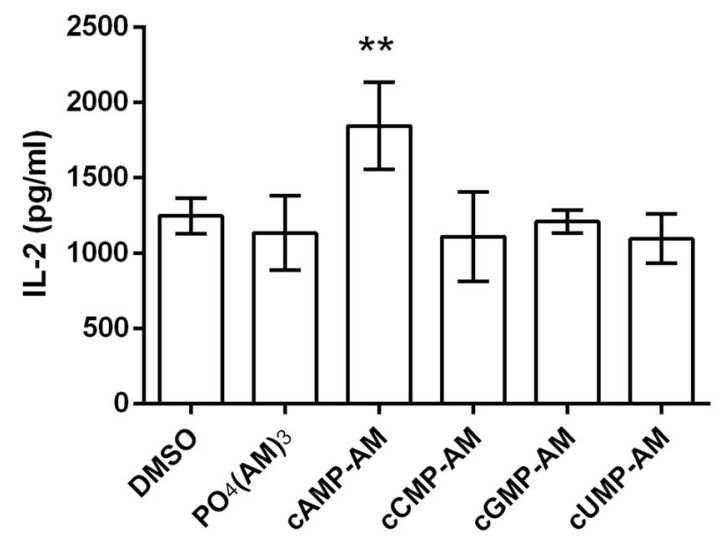

content of the cNMP-AM samples and for the intracellular hydrolysis products of the AM esters. Data shown are means \pm SD from $n=3$ independent experiments. Statistics: one-way ANOVA and Dunnet's multiple comparison test with medium (a) or $\mathrm{PO}_{4}(\mathrm{AM})_{3}$ (b) as control columns. Asterisks indicate significance level: $*=p<0.05 ; * *=p<0.01$

metabolic products formed by enzymes on the cell surface. To test this hypothesis, the effects of 5'-GMP (potential 3',5'cGMP hydrolysis product) and guanosine (possibly formed by degradation of $3^{\prime}, 5^{\prime}$-cGMP and/or 2',3'-cGMP) were
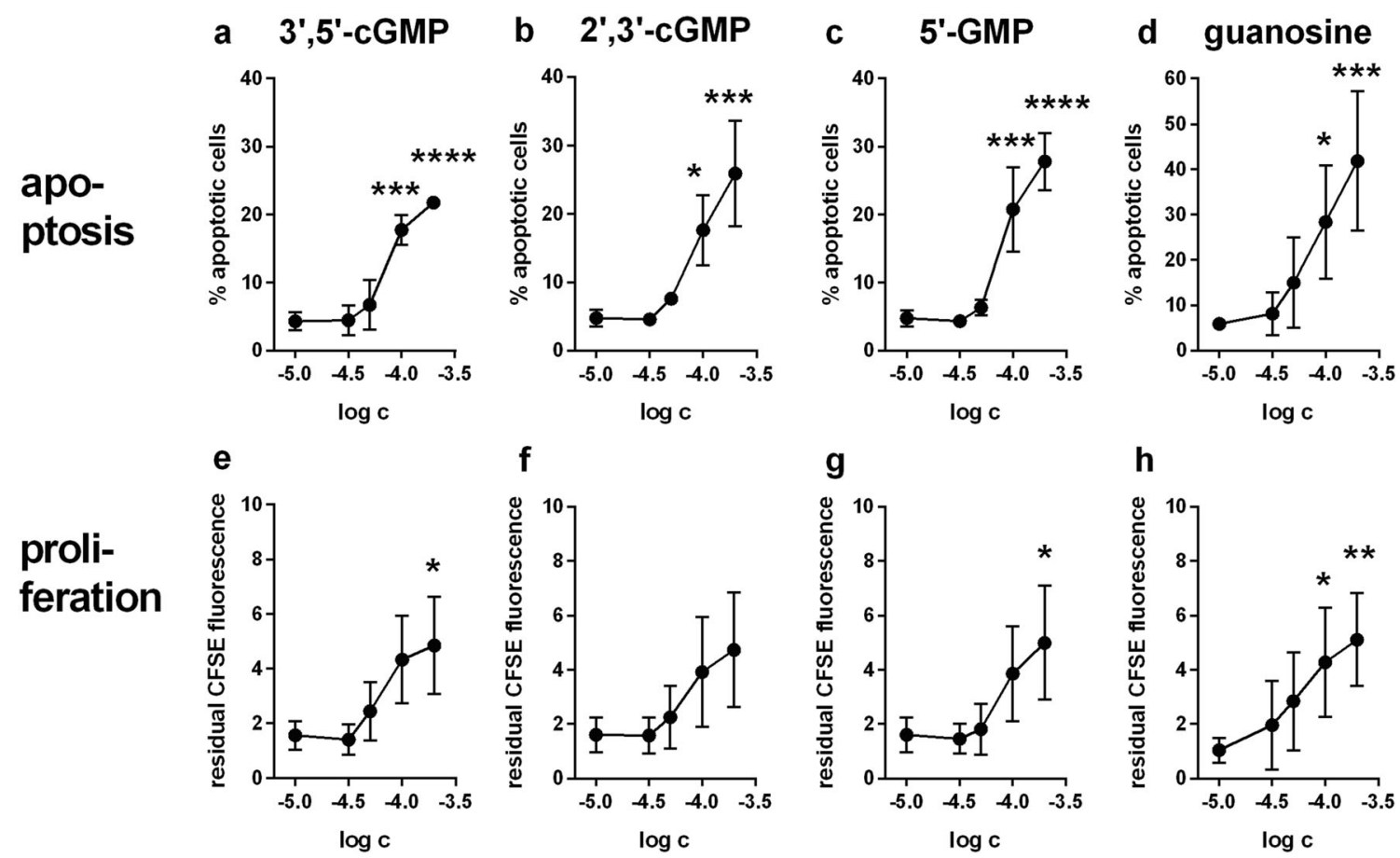

Fig. 2 Dose-dependent effect of 3',5'-cGMP, 2',3'-cGMP, 5'-GMP and guanosine on apoptosis and proliferation of HuT-78 lymphoma cells in the presence of $\alpha \mathrm{CD} 3$-antibody. Apoptosis $(\mathbf{a}-\mathbf{d})$ and proliferation $(\mathbf{e}-\mathbf{h})$ were determined by flow cytometry after $72 \mathrm{~h}$ of incubation with increasing concentrations of $3^{\prime}, 5^{\prime}$-cGMP (a, e), 2', 3'-cGMP (b, f), 5'GMP (c, g), and guanosine $(\mathbf{d}, \mathbf{h})$. Apoptosis was determined by combined staining with APC-labeled annexin V and propidium iodide; the anti-proliferative effect of cNMPs was determined via measuring the residual CFSE fluorescence at the end of the incubation time. Please note

that increased CFSE fluorescence means reduced proliferation (inverted relationship). Data are means \pm SD from $n=3$ (2', $3^{\prime}$-cGMP, 3', $5^{\prime}$-cGMP, and $5^{\prime}$-GMP) or $n=4$ (guanosine) independent experiments. In all graphs, the data point depicted at $\log -5.0$ represents the medium control and not a "real" $10 \mu \mathrm{M}$ concentration. Statistics: one-way ANOVA and Dunnet's multiple comparison test with medium control (data point at $\log -5.0$ ) as control value. Asterisks indicate significance level: $*=p<0.05$; $* *=p<0.01 ; * * *=p<0.001$ and $* * * *=p<0.0001$ 
investigated in apoptosis assays. In fact, both 5'-GMP (Fig. 2c) and guanosine (Fig. 2d) increased apoptosis of HuT-78 cells. This effect reached significance at concentrations of $100 \mu \mathrm{M}$ and $200 \mu \mathrm{M}$. In addition, in later experiments, we also demonstrated that $100 \mu \mathrm{M}$ of $2^{\prime}$-GMP (potential metabolite of 2',3'-cGMP) and 3'-GMP (potential metabolite of $2^{\prime}, 3^{\prime}$ - and $3^{\prime}, 5^{\prime}$-cGMP) exerted a highly significant apoptotic effect after $72 \mathrm{~h}$ of incubation (Fig. 3b).

Since pro-apoptotic action might be associated with an inhibition of proliferation, we also investigated the effect of the aforementioned guanosine-derived substances on HuT-78 cell proliferation in the CFSE assay. Residual CFSE fluorescence after $72 \mathrm{~h}$ of incubation was considerably increased by $100 \mu \mathrm{M}$ as well as $200 \mu \mathrm{M}$ of $3^{\prime}, 5^{\prime}$-cGMP, 2',3'-cGMP, 5'-GMP, and guanosine (Fig. 2e-h), indicating a strong anti-proliferative effect. Due to the large inter-experimental variability, however, the anti-proliferative effect only reached significance in case of 3',5'-cGMP (at $200 \mu \mathrm{M}$ ), of 5'-GMP (at $200 \mu \mathrm{M}$ ) and of guanosine (at $100 \mu \mathrm{M}$ and $200 \mu \mathrm{M}$ ) (Fig. 2e-h). In general, the apoptotic and anti-proliferative effects of the investigated guanosine-related compounds started to appear at a concentration of $50 \mu \mathrm{M}$, followed by a steep increase of activity between

\section{no inhibitor}
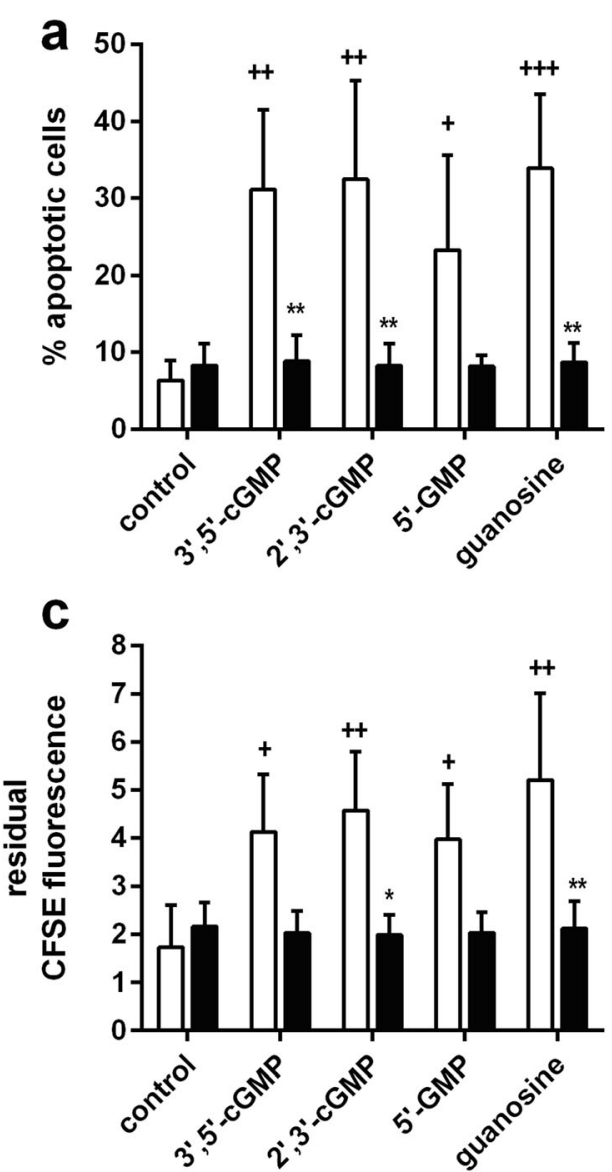

Fig. 3 Effect of the nucleoside transporter inhibitor NBMPR $(1 \mu \mathrm{M}$ and/or $10 \mu \mathrm{M}$ ) on apoptosis (a, b) and proliferation (c, d) of $\alpha \mathrm{CD} 3$-antibodystimulated HuT-78 cells treated with various guanosine-derived compounds $(100 \mu \mathrm{M})$. Two independent sets of experiments were conducted. Initially, the experiments included only $10 \mu \mathrm{M}$ of NBMPR (a, c). Later, $1 \mu \mathrm{M}$ of NBMPR was additionally included (b, d). For statistical reasons, the two sets were separately depicted and analyzed (two-way ANOVA not possible with partially missing groups). HuT 78 cells were incubated with the test compounds for $72 \mathrm{~h}$ in the presence of anti-CD3 antibody (OKT3). The samples contained no inhibitor (open bars) or $1 \mu \mathrm{M}$ of NBMPR (gray bars) or $10 \mu \mathrm{M}$ of NBMPR (black bars). Apoptosis (a, b) and proliferation (c, d) were determined by flow cytometry after $72 \mathrm{~h}$ of incubation (apoptosis: staining with APC-labeled annexin V and propidium iodide; proliferation: residual CFSE fluorescence at the end of the incubation time, higher residual CFSE fluorescence means less proliferation). Statistical results: Fig.
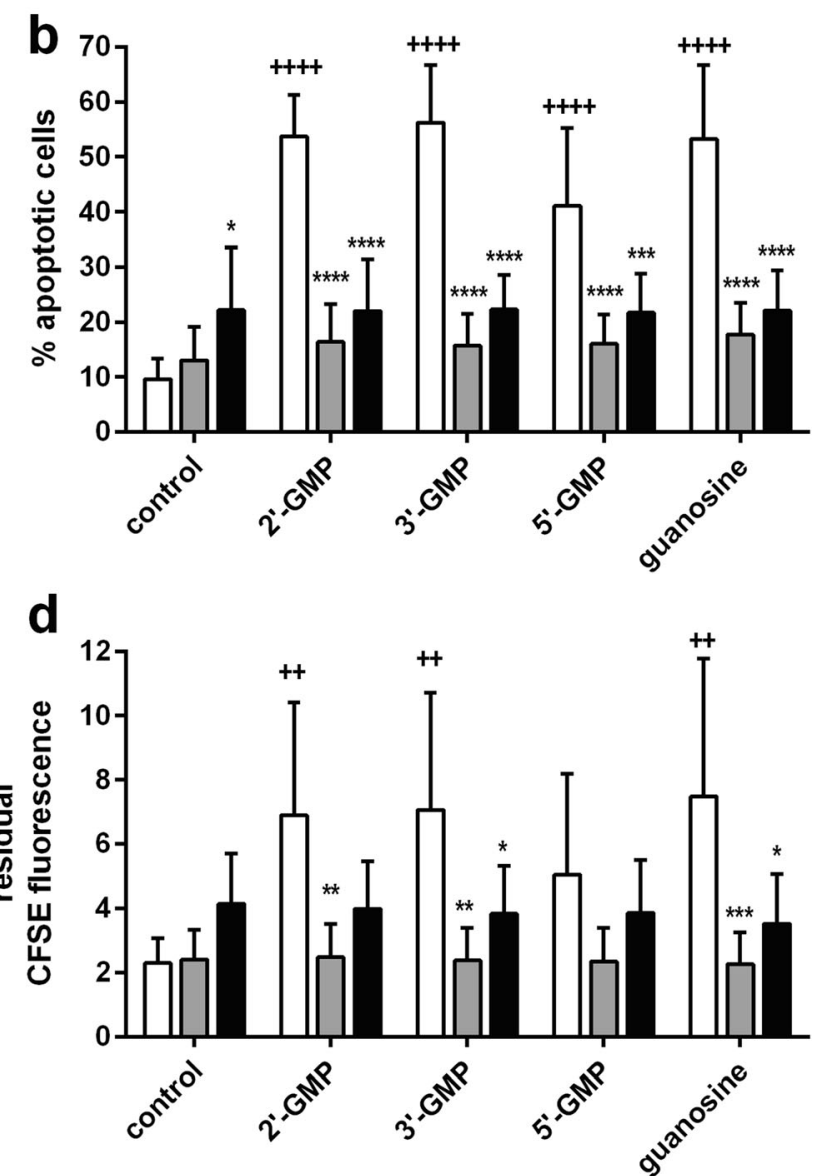

3a, c: Two-way ANOVA and Dunnet's multiple comparison test for comparison of guanosine nucleotide effects vs. control column; two-way ANOVA with Sidak's multiple comparisons test for comparison of inhibitor-containing samples vs. corresponding inhibitor-free controls. Figure 3b, d: two-way ANOVA and Dunnet's multiple comparison test for comparison of guanosine nucleotide effects vs. control column and for comparison of inhibitor-containing samples vs. corresponding inhibitor-free controls. One, two, three, and four symbols designate $p<0.05, p<0.01$, $p<0.001$, and $p<0.0001$, respectively. Significant differences between NBMPR-containing samples and the corresponding inhibitor-free samples are indicated by "**". Significant differences in comparison to the corresponding control columns are indicated by "+". Number of independent experiments: a, c: $n=3$ for both apoptosis and proliferation; b, d: $n=6$ (apoptosis) and $n=5$ (proliferation) 
50 and $100 \mu \mathrm{M}$ (Fig. 2a-h). A similarly pronounced antiproliferative effect was observed in later experiments performed under the same conditions with $100 \mu \mathrm{M}$ of $2^{\prime}$-GMP (potential metabolite of $2^{\prime}, 3^{\prime}$-cGMP) and of $3^{\prime}$-GMP (potential metabolite of 2',3'- and 3',5'-cGMP) (Fig. 3d). Interestingly, as shown in Suppl. Fig. 2, $100 \mu \mathrm{M}$ of the membrane-permeable cGMP-AM also exerted a strong apoptotic (Suppl. Fig. 2a) and anti-proliferative (Suppl. Fig. 2b) effect on HuT-78 cells, which is in contrast to its missing or only weak effect on $\alpha \mathrm{CD} 3$ induced IL-2 release in Fig. 1 or in Suppl. Fig. 3.

\section{Inhibition of anti-CD3 antibody-induced IL-2 production by products of $2^{\prime}, 3^{\prime}$-cGMP and/or 3',5'-cGMP metabolism}

The inhibitory effect of extracellular 3',5'-cGMP on IL-2 release of HuT-78 cells is associated with reduced HuT-78 cell proliferation and viability. In addition, later experiments have shown that the positional isomer $2^{\prime}, 3^{\prime}$-cGMP as well as the 2',3'-cGMP/3',5'-cGMP metabolites 2'-GMP, 3'-GMP, 5'GMP, and guanosine also exert apoptotic and antiproliferative effects. This prompted us to investigate whether these metabolites also inhibit IL-2 release. Indeed, ELISA experiments demonstrated that IL2 release of HuT-78 cells (in the presence of $\alpha \mathrm{CD} 3$ )-free samples is effectively inhibited by 2'-GMP, 3'-GMP, 5'-GMP, and guanosine (Suppl. Fig. 3).

However, the effects did not reach significance, and the absolute amount of IL-2 released was much lower than in previous experiments (compare Fig. 1 and Suppl. Fig. 3). The "w/o $\alpha$-CD3" control column in Suppl. Fig. 3 indicates that the HuT-78 cells showed already $\alpha$-CD3-independent baseline IL-2 production in these experiments, and IL-2 release was not further enhanced by $\alpha$-CD3 antibody. By contrast, in our previous experiments (Fig. 1), the IL-2 production by HuT78 cells was so effectively increased by $\alpha$-CD3 that the control column for $\alpha$-CD3 was omitted because it was almost zero and did not provide meaningful information. We have no explanation for the large and unpredictable discrepancies in IL-2 release from HuT-78 cells. By contrast, the apoptosis and proliferation measurements showed considerably better interexperimental reproducibility. For this reason, we focused on apoptosis and proliferation assays for the rest of the project.

\section{Role of equilibrative nucleoside transporters in mediating cytotoxicity of guanosine-derived compounds}

We hypothesized that both $3^{\prime}, 5^{\prime}$-cGMP and 2',3'-cGMP are first converted to mononucleotides by an ectophosphodiesterase on the cell surface, followed by the formation of guanosine by ectonucleotidases. This would mean that guanosine is the common anti-proliferative and pro-apoptotic metabolic end-product of $3^{\prime}, 5^{\prime}$-cGMP, 2',3'-cGMP, 5'-GMP,
3'-GMP, and 2'-GMP. Guanosine may then enter HuT-78 cells via a nucleoside transporter and unfold its cytotoxic effects from inside the cell.

To test this hypothesis, HuT-78 cells were incubated with guanosine and guanosine nucleotides in the presence and absence of S-(4-Nitrobenzyl)-6-thioinosine (NBMPR), which preferentially inhibits the human equilibrative nucleoside transporter hENT1. According to the literature, the $\mathrm{IC}_{50}$ value for nucleoside transport inhibition by NBMPR is $0.4 \mathrm{nM}$ and $2.8 \mu \mathrm{M}$ for hENT1 and hENT2, respectively (Ward et al. 2000). Thus, we used a concentration of $10 \mu \mathrm{M}$ of NBMPR, which should be sufficient to completely inhibit guanosine uptake by hENT1 and which should only partially block hENT2. Again, $100 \mu \mathrm{M}$ of guanosine, 5'-GMP, 2',3'-cGMP, or 3', 5'cGMP significantly promoted apoptosis (Fig. 3a) and inhibited proliferation (Fig. 3c) (two-way ANOVA and Dunnet's multiple comparison test, comparisons with corresponding control column). The hENT1 inhibitor NBMPR was clearly protective and inhibited the pro-apoptotic and anti-proliferative actions of the tested guanosine-derived compounds (Fig. 3a, c). The protective NBMPR effect reached significance for $2^{\prime}, 3^{\prime}$-cGMP, $3^{\prime}, 5^{\prime}$-cGMP, and guanosine in the apoptosis experiments (Fig. $3 \mathrm{a}$ ) and for $2^{\prime}, 3^{\prime}$-cGMP and guanosine in the proliferation assay (Fig. 3c) (two-way ANOVA with Sidak's multiple comparisons test for comparison of inhibitor-containing samples with corresponding inhibitor-free controls). Later in the project, we performed a second set of experiments that included not only $10 \mu \mathrm{M}$ of NBMPR but also the lower concentration of $1 \mu \mathrm{M}$. Even at a concentration of only $1 \mu \mathrm{M}$, NBMPR protected HuT78 cells from the cytotoxic effects of $100 \mu \mathrm{M}$ of the $2^{\prime}, 3^{\prime}$-cGMP and/or 3',5'-cGMP metabolites 2'-GMP, 3'-GMP, 5'-GMP, and guanosine. This is illustrated for apoptosis in Fig. $3 \mathrm{~b}$ and for proliferation in Fig. 3d. Interestingly, Fig. 3b, d show that NBMPR has already a maximum protective effect at a concentration of $1 \mu \mathrm{M}$. By contrast, $10 \mu \mathrm{M}$ of NBMPR seem to be slightly cytotoxic, as indicated by a weak apoptotic and antiproliferative effect (Fig. 3b, d).

Moreover, NBMPR counteracted the inhibitory effect of 2'GMP, 3'-GMP, 5'-GMP, and guanosine on IL-2 release, although the effects did not reach significance (ELISA data in Suppl. Fig. 3). Suppl. Fig. 3 again indicates that $1 \mu \mathrm{M}$ of NBMPR is already sufficient to cause the maximum protective effect in the IL-2 assay.

\section{Determination of the $\mathrm{IC}_{50}$ value of NBMPR}

The results reported so far suggest that 2',3'-cGMP and 3',5'cGMP are metabolized to the end-product guanosine, which is taken up into the cell by an NBMPR-sensitive nucleoside transporter and then exerts apoptotic and anti-proliferative effects. The two most important nucleoside transporters for guanosine, ENT1 and ENT2, show largely different $\mathrm{IC}_{50}$ values for NBMPR (see Table 1: $0.4 \mathrm{nM}$ for ENT1 and $2.8 \mu \mathrm{M}$ for 
ENT2). A third, yet undefined transporter is responsible for the csg guanosine transport process and is inhibited by NBMPR with a $K_{i}$ value of $0.7 \mathrm{nM}$.

To learn more about the identity of the transporter responsible for the observed guanosine effects in HuT-78 cells, we recorded concentration-effect curves for apoptosis (Fig. 4a) and proliferation (Fig. 4b) with increasing concentrations of NBMPR in the presence of $100 \mu \mathrm{M}$ of guanosine (red curves in Fig. 4). Since NBMPR exerts an apoptotic and antiproliferative effect by itself at higher concentrations (cf. data shown in the preceding section), we additionally determined a concentration-effect curve in the absence of guanosine (black curves in Fig. 4). This background effect of NBMPR alone was subtracted from the guanosine + NBMPR data, yielding the net effect of guanosine in the presence of increasing NBMPR concentrations (blue curves in Fig. 4). The $\mathrm{IC}_{50}$ value of NBMPR was $\sim 25 \mathrm{nM}$ in the apoptosis assays and $\sim 28 \mathrm{nM}$ in the proliferation experiments.

\section{Role of ecto-phosphodiesterase and ecto-5'-nucleotidase in mediating cytotoxicity of guanosine nucleotides}

After having shown that NBMPR-sensitive nucleoside transport is the common mechanism for the cytotoxic effects of guanosine and guanosine-derived nucleotides, we addressed the steps that may lead to guanosine formation from the corresponding cyclic nucleotides and mononucleotides. First, we investigated the effect of DPSPX (1,3dipropyl-8-sulfophenylxanthine), which is not only a well-known adenosine receptor antagonist but also an inhibitor of ecto-phosphodiesterases. Cells were incubated with $100 \mu \mathrm{M}$ of DPSPX during the first $24 \mathrm{~h}$. After $24 \mathrm{~h}$ and $48 \mathrm{~h}, 100 \mu \mathrm{M}$ of fresh DPSPX were added to compensate for potential hydrolytic inactivation. Thus, in the absence of DPSPX hydrolysis, the DPSPX concentration in the samples would reach $300 \mu \mathrm{M}$ after $72 \mathrm{~h}$. However,

Table 1 Important transport processes for nucleosides and nucleoside analogues

\begin{tabular}{|c|c|c|c|c|c|}
\hline Process & Protein & Expression & $\begin{array}{l}\text { Examples for physiological } \\
\text { substrates }\left(\mathrm{K}_{\mathrm{m}}\right)\end{array}$ & $\begin{array}{l}\text { Examples for nonphysiological } \\
\text { substrates }\left(\mathrm{K}_{\mathrm{m}}\right)\end{array}$ & $\begin{array}{l}\text { NBMPR } \\
\text { sensitive? } \\
\left(\mathrm{IC}_{50}\right)\end{array}$ \\
\hline \multicolumn{6}{|c|}{ Equilibrative, bidirectional facilitators (ENT transporter family: SLC29) } \\
\hline es & hENT1 & ubiquitous & $\begin{array}{l}\text { adenosine }(50 \mu \mathrm{M}) \\
\text { guanosine }(140 \mu \mathrm{M}) \\
\text { inosine }(200 \mu \mathrm{M}) \\
\text { uridine }(480 \mu \mathrm{M}) \\
\text { thymidine }(240 \mu \mathrm{M}) \\
\text { cytidine }(680 \mu \mathrm{M})\end{array}$ & $\begin{array}{l}\text { gemcitabine }(160 \mu \mathrm{M}) \\
\text { cytarabine } \\
\text { fludarabine } \\
\text { cladribine }\end{array}$ & yes $(0.4 \mathrm{nM})$ \\
\hline$e i$ & hENT2 & $\begin{array}{l}\text { ubiquitous, high abundance in } \\
\text { skeletal muscle }\end{array}$ & $\begin{array}{l}\text { adenosine }(140 \mu \mathrm{M}) \\
\text { guanosine }(2700 \mu \mathrm{M}) \\
\text { inosine }(50 \mu \mathrm{M}) \\
\text { uridine }(270 \mu \mathrm{M}) \\
\text { thymidine }(620 \mu \mathrm{M}) \\
\text { cytidine }(5210 \mu \mathrm{M})\end{array}$ & $\begin{array}{l}\text { gemcitabine }(740 \mu \mathrm{M}) \\
\text { cladribine } \\
\text { cytarabine } \\
\text { fludarabine }\end{array}$ & no $(2.8 \mu \mathrm{M})$ \\
\hline- & hENT3 & $\begin{array}{l}\text { ubiquitous, e.g. placenta, mainly } \\
\text { intracellular, optimum activity } \\
\text { at } \mathrm{pH} 5.5\end{array}$ & $\begin{array}{l}\text { adenosine }(1900 \mu \mathrm{M}) \\
\text { uridine }(2000 \mu \mathrm{M})\end{array}$ & e.g. gemcitabine & no \\
\hline- & hENT4 (PMAT) & ubiquitous & $\begin{array}{l}\text { adenosine }(780 \mu \mathrm{M}) \text {, organic } \\
\text { cations including } \\
\text { serotonin }(1900 \mu \mathrm{M})\end{array}$ & $\begin{array}{l}\text { 1-methyl-4-phenylpyridinium } \\
\left(\mathrm{MPP}^{+}, \text {neurotoxin }\right)\end{array}$ & no \\
\hline \multicolumn{6}{|c|}{ Concentrative, inwardly directed sodium/nucleoside cotransporters (CNT transporter family: SLC 28) } \\
\hline cit & hCNT1 & $\begin{array}{l}\text { e.g. epithelial tissues of small } \\
\text { intestine, kidney and liver }\end{array}$ & adenosine, pyrimidine nucleosides & $\begin{array}{l}\text { zidovudine, lamivudine, } \\
\text { gemcitabine }(17 \mu \mathrm{M}) \text {, } \\
\text { cytarabine, 5'-DFUR } \\
(209 \mu \mathrm{M})\end{array}$ & no \\
\hline cif & hCNT2 & $\begin{array}{l}\text { numerous tissues, e.g. kidney, } \\
\text { liver, heart, brain, placenta, } \\
\text { pancreas }\end{array}$ & purine nucleosides, uridine & didanosine, ribavirin & no \\
\hline$c i b$ & hCNT3 & $\begin{array}{l}\text { e.g. pancreas, trachea, bone } \\
\text { marrow, mammary gland }\end{array}$ & purine and pyrimidine nucleosides & $\begin{array}{l}\text { gemcitabine, fludarabine, } \\
\text { cladribine }\end{array}$ & no \\
\hline $\operatorname{csg}$ & $? ? ?$ & $\begin{array}{l}\text { NB4 promyelocytic leukemia } \\
\text { cells, L1210 murine acute } \\
\text { lymphocytic leukemia cells }\end{array}$ & guanosine & $? ? ?$ & yes $(0.7 \mathrm{nM})$ \\
\hline
\end{tabular}

The information in this table comes from the following publications: (Flanagan and Meckling-Gill 1997; Ward et al. 2000; Young et al. 2008; Pastor-Anglada et al. 2004; Gray et al. 2004; Govindarajan et al. 2009). Please note that this table is not exhaustive and does not completely cover the literature on substrate selectivity of nucleoside transporters. Abbreviations: PMAT = Plasma membrane monoamine transporter; 5'-DFUR = 5'-Deoxy-5-fluorouridine 
Fig. 4 Effect of increasing concentrations of NBMPR on apoptosis (a) and proliferation (b) of HuT-78 cells in the presence (red curve) and in the absence (black curve) of $100 \mu \mathrm{M}$ of guanosine. The blue curve represents the difference between red and black curve, i.e. the net effect of guanosine after subtraction of the "NBMPR background". Apoptosis (a) and proliferation (b) were determined by flow cytometry after $72 \mathrm{~h}$ of incubation (apoptosis: combined staining with APC-labeled annexin $\mathrm{V}$ and propidium iodide; proliferation: quantitation of residual CFSE fluorescence at the end of the incubation time, higher residual CFSE fluorescence means less proliferation). Data are means $\pm \mathrm{SD}$ from $n=5$ (apoptosis) and $n=3$ (proliferation) independent experiments
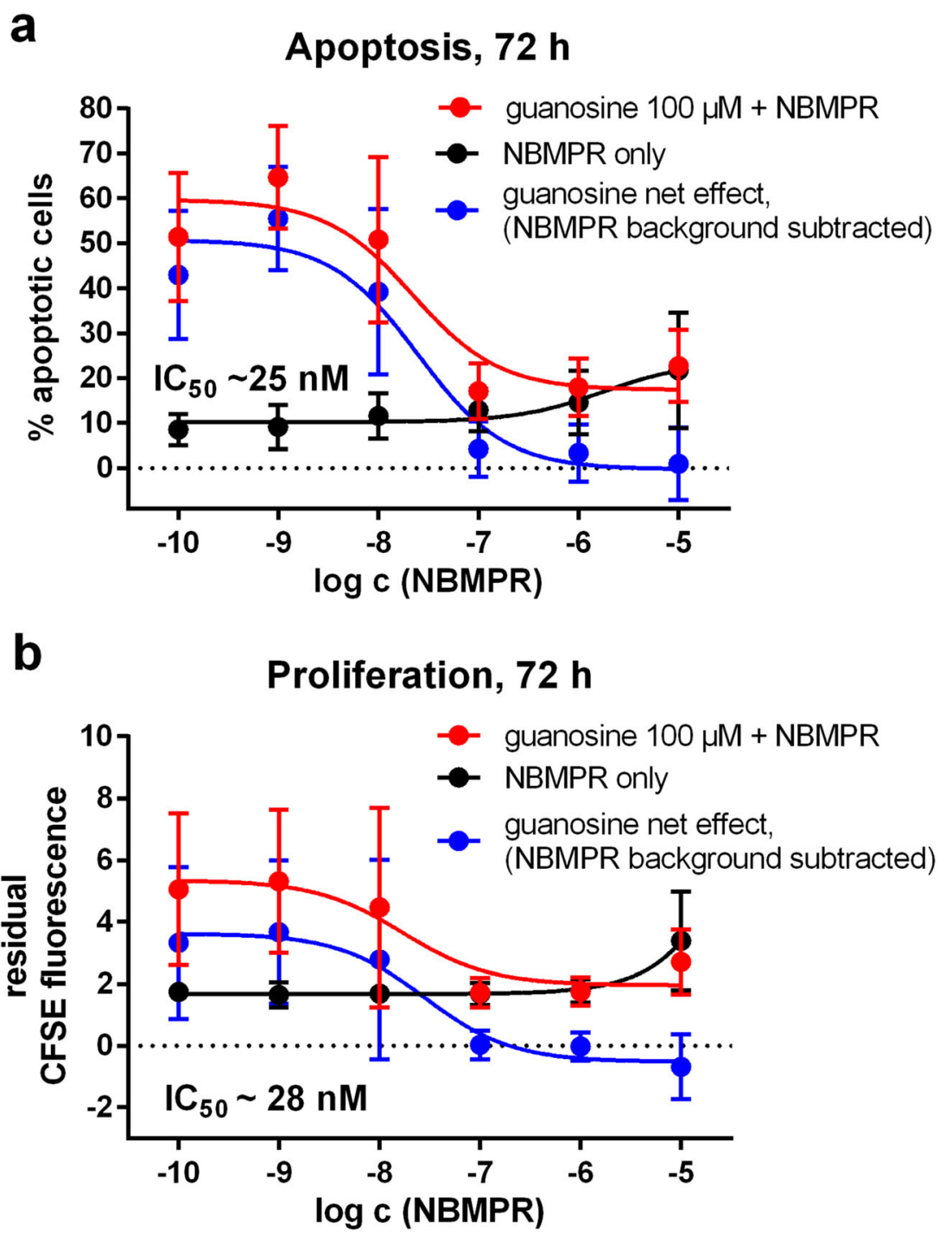

DPSPX did not inhibit the pro-apoptotic (Fig. 5a) and antiproliferative (Fig. 5b) effects of 2',3'-cGMP, 3',5'-cGMP, 5'-GMP, and guanosine.

Second, we analyzed whether AMP-CP (adenosine $5^{\prime}$-( $\alpha, \beta$-methylene)diphosphate), an inhibitor of the ecto5 '-nucleotidase CD73, was able to modulate the effects of 5'-GMP on HuT-78 cell apoptosis and proliferation. Since guanosine would not require CD73 for its activation, it was selected as a negative control. Even after $72 \mathrm{~h}$ of incubation with $100 \mu \mathrm{M}$ of AMP-CP, no alteration of the pro-apoptotic (Fig. 6a) or anti-proliferative (Fig. 6b) effects of 5-GMP (black bars in Fig. 6a, b) and guanosine (gray bars in Fig. 6a, b) was observed. To compensate for potential hydrolysis of AMP-CP, other samples were run in parallel, where $100 \mu \mathrm{M}$ of fresh AMP-CP was added after $24 \mathrm{~h}$ and $48 \mathrm{~h}$ (similar as described above for DPSPX; bars labeled with "AMP-CP (daily)" in Fig. $6 \mathrm{a}, \mathrm{b})$. However, no effect of AMP-CP was observed in these samples either.
Effects of 3',5'-cIMP, 3',5'-cAMP, and adenosine as well as of $2^{\prime}, 3^{\prime}-$ and $3^{\prime}, 5^{\prime}$-cyclic pyrimidine nucleotides on HuT-78 cell apoptosis and proliferation

As shown in Fig. 1, unlike 3',5'-cGMP, the structurally closely related cyclic nucleotide $3^{\prime}, 5^{\prime}$-cIMP had no influence on $\alpha \mathrm{CD} 3$-antibody-induced IL2-production. Therefore, we investigated if this also pertains to apoptosis and proliferation. In fact, neither $100 \mu \mathrm{M}$ nor $200 \mu \mathrm{M}$ of $3^{\prime}, 5^{\prime}$-cIMP altered apoptosis (Fig. 7a) or proliferation (Fig. 7c) of HuT-78 cells. The other purine cyclic nucleotide, $3^{\prime}, 5^{\prime}$-cAMP, was also ineffective at $100 \mu \mathrm{M}$ in both readouts (Fig. 7a, c), confirming the results from the IL2 ELISA experiments. Only at a concentration of $200 \mu \mathrm{M}, 3^{\prime}, 5^{\prime}$-cAMP exerted a highly significant apoptotic and anti-proliferative effect (apoptosis: $p<0.0001$; proliferation: $p<0.01$; compared with medium control; twoway ANOVA with Dunnet's multiple comparison test; Fig. $7 \mathrm{a}, \mathrm{c})$. By contrast, the positional isomer 2',3'-cAMP was neither pro-apoptotic nor anti-proliferative (Fig. 7b, d). 
a

Apoptosis

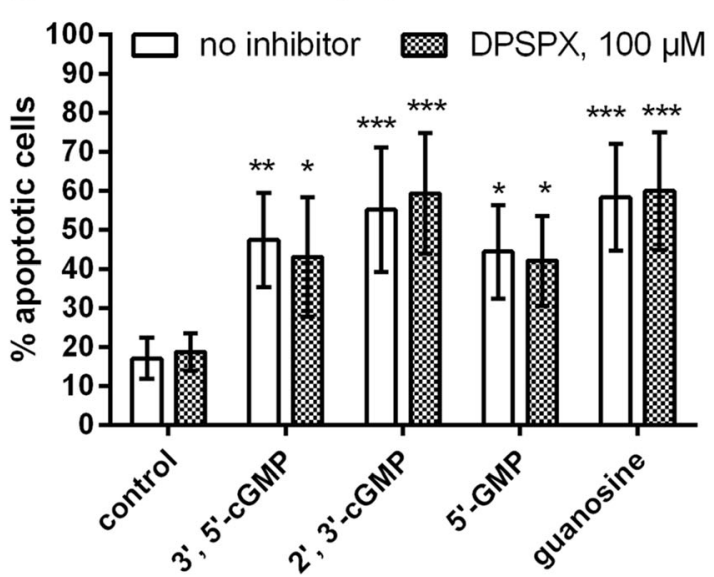

Fig. 5 Effect of the ecto-phosphodiesterase inhibitor DPSPX on the proapoptotic (a) and anti-proliferative (b) actions of $100 \mu \mathrm{M}$ of 3',5'-cGMP, 2',3'-cGMP, 5'-GMP, and guanosine on $\alpha \mathrm{CD} 3$-antibody-stimulated HuT78 lymphoma cells. Cells were incubated with guanosine-related compounds in the absence (open bars) or presence (filled bars) of the ecto-phosphodiesterase inhibitor DPSPX. $100 \mu \mathrm{M}$ of fresh inhibitor were added at $t=0 \mathrm{~h}, 24 \mathrm{~h}$, and $48 \mathrm{~h}$ to compensate for potential hydrolysis (maximum possible concentration at $72 \mathrm{~h}: 300 \mu \mathrm{M}$ ). Apoptosis (a) and proliferation (b) were determined by flow cytometry

Adenosine, a potential metabolic product of both $2^{\prime}, 3^{\prime}$ - or $3^{\prime}, 5^{\prime}$-cAMP, was inactive with regard to proliferation (Fig. $7 \mathrm{~d})$ but significantly active at $200 \mu \mathrm{M}$ in the apoptosis assay $(p<0.01$ compared with medium control; two-way ANOVA

a

Apoptosis

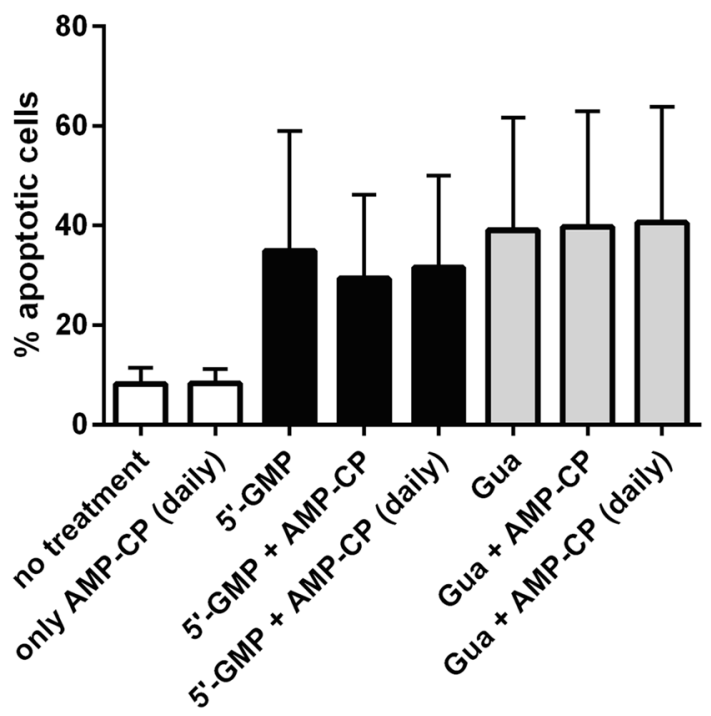

Fig. 6 Effect of the 5'-ectonucleotidase (CD73) inhibitor AMP-CP on the pro-apoptotic (a) and anti-proliferative (b) actions of $100 \mu \mathrm{M}$ of 5'-GMP or guanosine (HuT-78 lymphoma cells in the presence of $\alpha \mathrm{CD} 3$ antibody). Cells were incubated with guanosine-derived compounds (black bars: 5'-GMP; gray bars: guanosine) in the absence or presence of $100 \mu \mathrm{M}$ of the ecto-5'-nucleotidase inhibitor AMP-CP as designated in the $\mathrm{x}$-axis labeling. The inhibitor was either added only once in the beginning at $t=0 \mathrm{~h}$, or it was added freshly every day (at $t=0 \mathrm{~h}, 24 \mathrm{~h}$, b

\section{Proliferation}

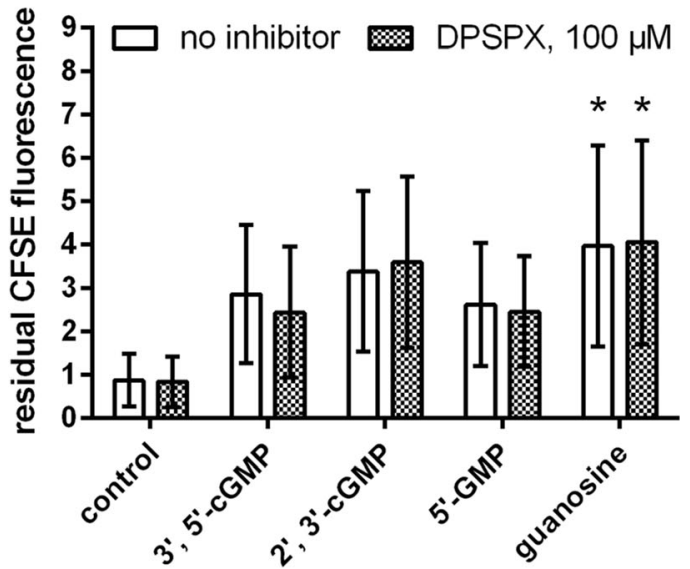

after $72 \mathrm{~h}$ of incubation. Apoptosis was determined by combined staining with APC-labeled annexin V and propidium iodide; the antiproliferative effect of cNMPs was determined via measuring the residual CFSE fluorescence at the end of the incubation time. Higher residual CFSE fluorescence means less proliferation. Statistics: asterisks indicate significant effect of treatment with guanosine-derived compounds (twoway ANOVA and Dunnet's multiple comparison test, comparisons with corresponding control column). Data are means \pm SD from $n=4$ independent experiments

with Dunnet's multiple comparison test; Fig. 7b). The cyclic pyrimidine nucleotides $3^{\prime}, 5^{\prime}$-cCMP and 3',5'-cUMP that had been ineffective at inhibiting $\alpha \mathrm{CD} 3$ antibody-induced IL2release were also completely inactive with respect to apoptosis

b

Proliferation

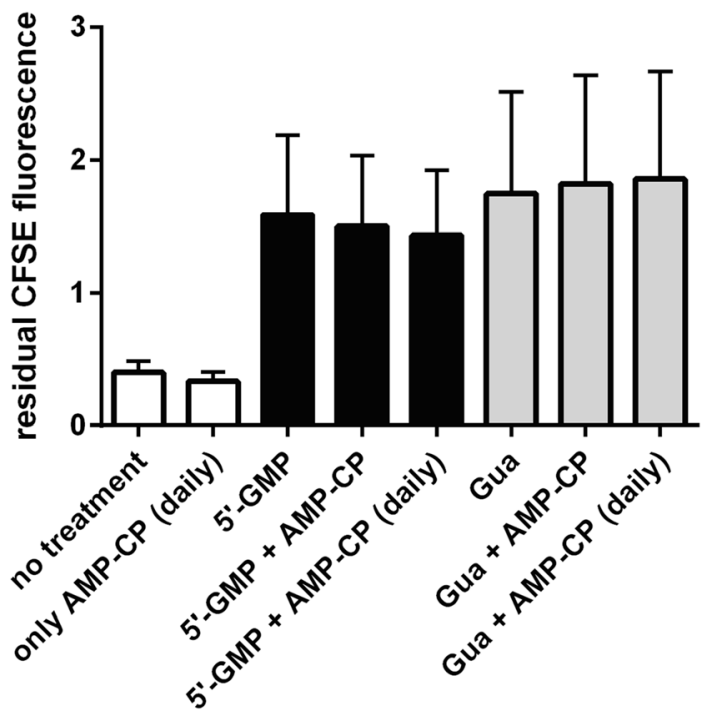

and $48 \mathrm{~h}$; indicated as "AMP-CP (daily)" in the labeling of the bars). In both cases, the total incubation time lasted $72 \mathrm{~h}$. Apoptosis (a) and proliferation (b) were determined by flow cytometry. Apoptosis was determined by combined staining with APC-labeled annexin V and propidium iodide; the anti-proliferative effect was determined via measuring the residual CFSE fluorescence at the end of the incubation time. Higher residual CFSE fluorescence means lower proliferation. Data are means $\pm \operatorname{SD}$ from $n=2$ independent experiments 

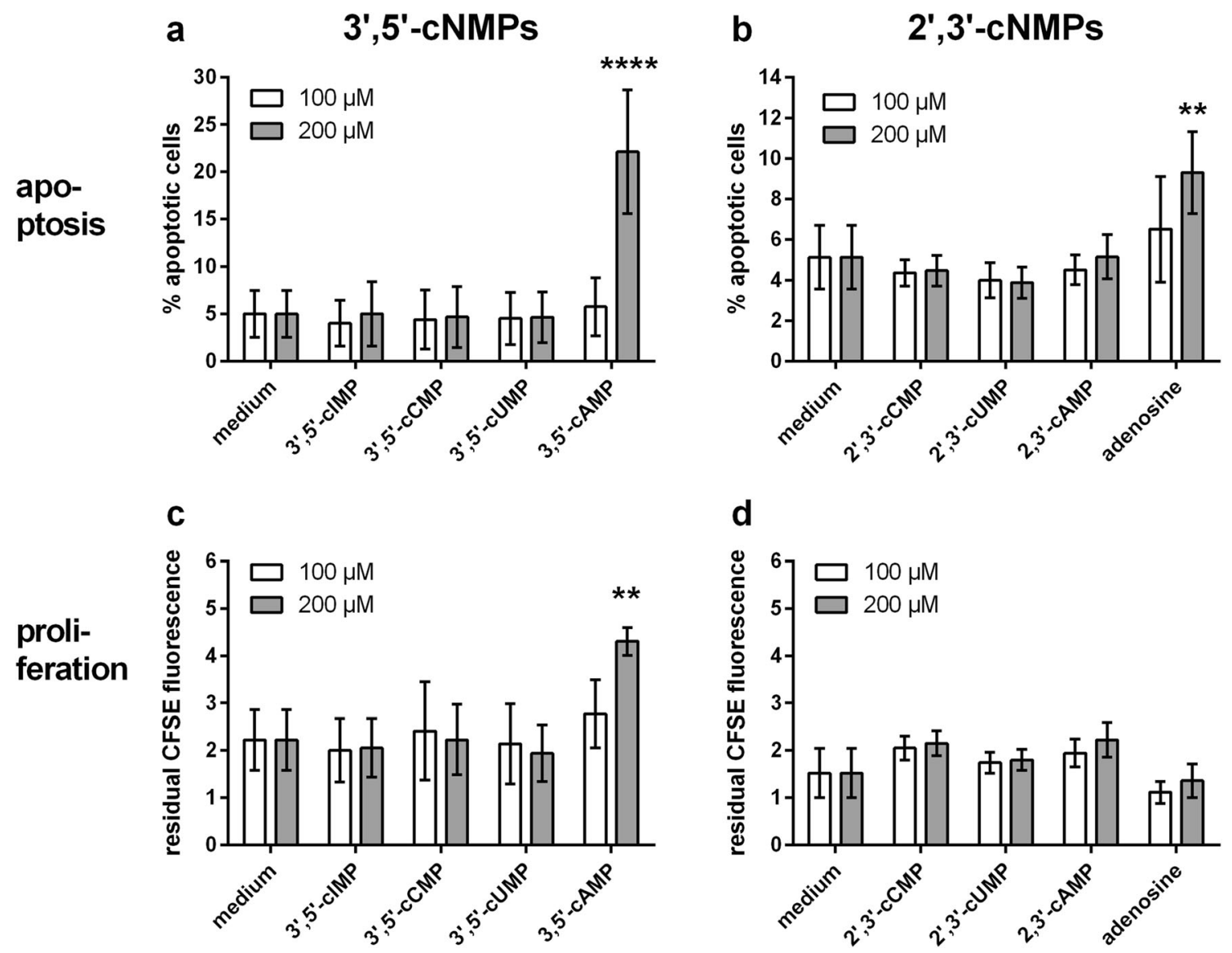

Fig. 7 Effect of unmodified non-guanosine-related 3',5'- and 2',3'-cNMPs and adenosine on apoptosis and proliferation of $\alpha \mathrm{CD} 3$-antibody-stimulated HuT-78 lymphoma cells. Cells were incubated with $100 \mu \mathrm{M}$ (open bars) or $200 \mu \mathrm{M}$ (filled bars) of 3',5'-cNMPs (a, c) or 2',3'-cNMPs (b, d). Apoptosis $(\mathbf{a}, \mathbf{b})$ and proliferation $(\mathbf{c}, \mathbf{d})$ were determined by flow cytometry after $72 \mathrm{~h}$ of incubation. Apoptosis was determined by combined staining with APClabeled annexin $\mathrm{V}$ and propidium iodide; the anti-proliferative effect of cNMPs was determined via measuring the residual CFSE fluorescence at

(Fig. 7a) and proliferation (Fig. 7c), even at a concentration of $200 \mu \mathrm{M}$. Likewise, the positional isomers $2^{\prime}, 3^{\prime}$-cCMP and $2^{\prime}, 3^{\prime}$-cUMP did not influence the readouts for apoptosis (Fig. $7 \mathrm{~b})$ and proliferation (Fig. 7d).

\section{Cytotoxicity of guanosine and guanosine-related compounds on PBMCs/T cells and acute lymphoblastic leukemia (ALL) xenografts}

Since HuT-78 cells are lymphoma cells and the properties of cancer cell lines frequently differ from those of primary cells, we conducted additional experiments with freshly isolated PBMCs that also contain T lymphocytes. Since the PBMCs were incubated throughout the experiment (i.e., for $72 \mathrm{~h}$ ) in the presence of anti-CD3 (OKT3) and anti-CD28 antibody, the proportion of T cells was further increased. In fact, these cells behaved very differently. Unlike in HuT-78 cells, none of the guanosinerelated compounds induced apoptosis (Fig. 8a; open bars). the end of the incubation time. Higher residual CFSE fluorescence means less proliferation. Data are means $\pm \mathrm{SD}$ from $n=3\left(2^{\prime}, 3^{\prime}\right.$ - and 3',5'-cNMPs) or $n=2$ (adenosine) independent experiments. Statistics: two-way ANOVA and Dunnet's multiple comparison test (related to medium as control). Separate comparisons were performed for the $100 \mu \mathrm{M}$ and the $200 \mu \mathrm{M}$ column. Asterisks indicate significance level: $*=\mathrm{p}<0.05 ; * *=\mathrm{p}<0.01$ and $* * * *=\mathrm{p}<0.0001$

Consequently, NBMPR $(10 \mu \mathrm{M})$ did also not modulate any of these readouts in PBMCs (Fig. 8a; filled bars).

Since guanosine-related compounds were only active in HuT-78 cells but not in PBMCs, they may have therapeutic potential for the treatment of T cell lymphomas. Such compounds may selectively kill lymphoma cells without affecting the healthy $\mathrm{T}$ cell population. To elucidate whether the observed apoptotic and anti-proliferative effects also pertain to other lymphomas, we investigated the effect of $100 \mu \mathrm{M}$ of 2',3'-cGMP, 3',5'-cGMP, 5'-GMP, and guanosine on cortical $\mathrm{T}$ cell acute lymphoblastic leukemia (ALL) xenograft cells. Adenosine $(100 \mu \mathrm{M})$ was also investigated as a "non-guanosine negative control." The xenografts had been previously produced by growing patient-derived tumor cells in immunologically deficient NSG mice (Frismantas et al. 2017). In contrast to conventional cancer cell lines, xenografts have the advantage that their characteristics are very close to primary cancer cells since they retain the pattern of mutations present in the 

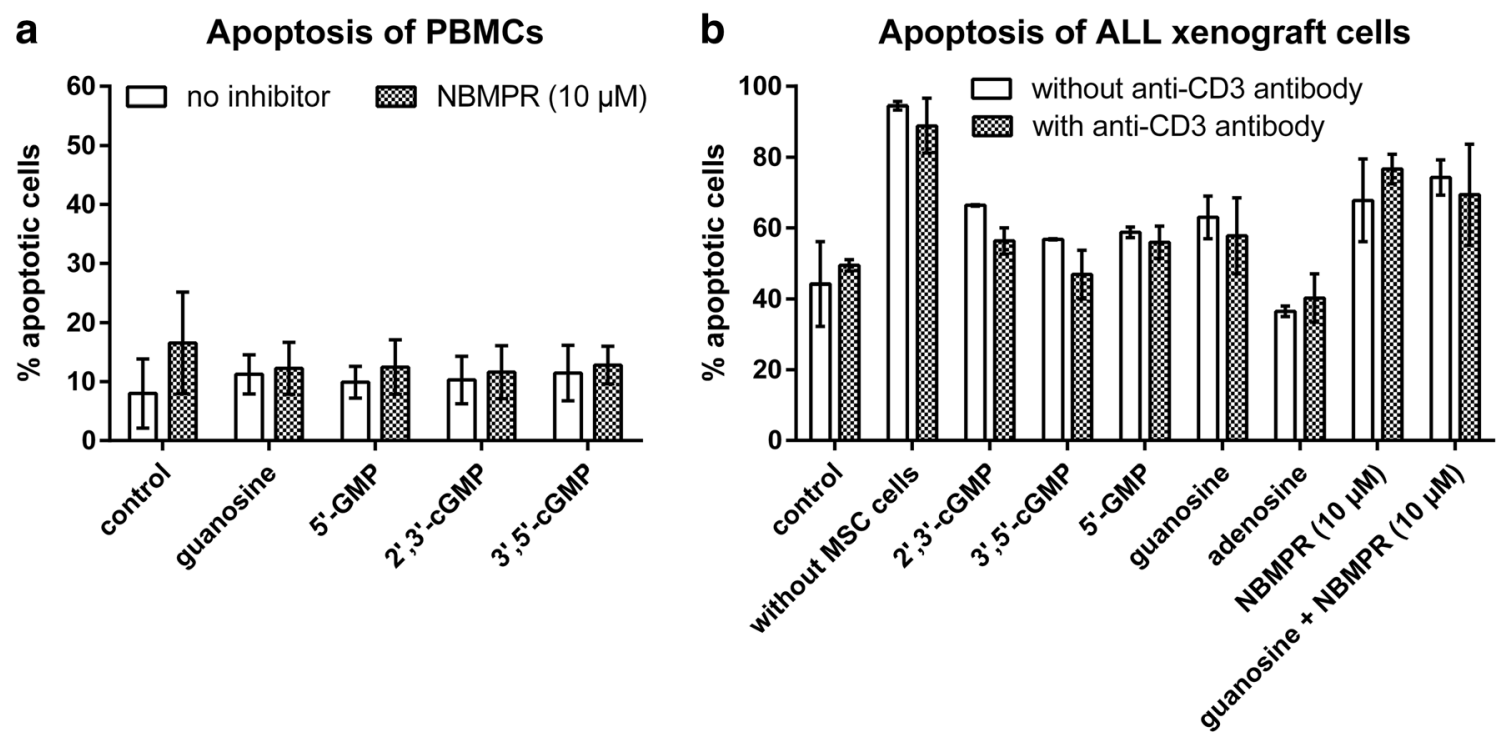

Fig. 8 Apoptotic effects of guanosine-related compounds on PBMCs (a) and cortical T cell ALL xenograft cells (b). All compounds were tested at a concentration of $100 \mu \mathrm{M}$. PBMCs (a) were incubated for $72 \mathrm{~h}$ with $100 \mu \mathrm{M}$ of the test compounds in the presence of anti-CD3- and antiCD28-antibody. ALL xenograft cells (b) were co-cultured with mesenchymal stem cells (MSC cells) for $72 \mathrm{~h}$ in the absence of anti-

original patient-derived material (Frismantas et al. 2017). Our experiment was conducted under similar conditions as used for the HuT-78 cells on anti-CD3-antibody-treated plates. However, unlike the HuT-78 cells, the xenograft cells were cultured in the presence of feeder cells (mesenchymal stem cells, MSC) as described by Frismantas et al. (2017). Moreover, a second set of wells was used to perform the experiment in the absence of anti-CD3 coating. Figure $8 \mathrm{~b}$ shows that basal apoptosis under control conditions was already relatively high $(40-50 \%)$ but independent of the presence of anti-CD3 antibody. Control wells without MSC feeder cells showed almost $100 \%$ apoptosis, indicating that MSC cells are absolutely necessary for the viability of the xenograft cells. The guanosinederived compounds had no significant effect. Only a weak proapoptotic trend was observed (increase by about 10\%, Fig. 8b). However, $10 \mu \mathrm{M}$ of NBMPR did not protect the cells, when combined with $100 \mu \mathrm{M}$ of guanosine (Fig. 8b). Interestingly, the lowest apoptosis rate was observed in the presence of $100 \mu \mathrm{M}$ of adenosine, suggesting a protective effect.

\section{Discussion}

\section{Apoptotic and anti-proliferative effects of guanosine-related compounds}

Prompted by the observation that 3',5'-cGMP inhibits $\alpha \mathrm{CD} 3$ antibody-stimulated IL-2 production of HuT-78 T-lymphoma cells, we have performed a detailed investigation of the effects of guanosine-related compounds on HuT-78 cell apoptosis

CD3 antibody (open bars) and in the presence of anti-CD3 antibody (filled bars). The nucleoside transport inhibitor NBMPR was used at a concentration of $10 \mu \mathrm{M}$. Apoptosis was determined by combined staining with APC-labeled annexin V and propidium iodide. Data are means \pm SD from $n=4$ (a) or $n=2$ (b) independent experiments

and proliferation. We have mainly focused on apoptosis and proliferation data because they showed lower interexperimental variability than anti-CD3 antibody-stimulated IL-2 production. The results presented in this publication demonstrate that guanosine as well as the guanosine-related nucleotides 2', 3'-cGMP, 3', 5'-cGMP, 2'-GMP, 3'-GMP, and 5'GMP increase apoptosis and reduce proliferation of HuT-78 T lymphoma cells. It is unlikely that these effects are caused by activation of adenosine receptors because adenosine was active in apoptosis assays only at a high concentration of $200 \mu \mathrm{M}$ and completely ineffective in proliferation experiments. Moreover, DPSPX, which is not only an ectophosphodiesterase inhibitor but also a non-selective adenosine receptor antagonist, did not eliminate the effects of the tested guanosine-related compounds. We developed several hypotheses to explain our observations (Fig. 9).

\section{First hypothesis: guanosine is formed extracellularly and taken up into HuT-78 cells by an NBMPR-sensitive nucleoside transporter}

First, we hypothesized that the cytotoxic effects of $2^{\prime}, 3^{\prime}-/ 3^{\prime}, 5^{\prime}-$ cGMP as well as 2'-GMP, $3^{\prime}$-GMP and 5'-GMP are caused by guanosine, which is formed by enzymatic breakdown of the nucleotides and enters the cells through NBMPR-sensitive nucleoside transporters. The guanosine-cNMPs could be hydrolyzed to mononucleotides by ecto-phosphodiesterases (Fig. 9, step 1), followed by the formation of guanosine after further ectonucleotidase-mediated digestion (Fig. 9, step 2). In fact, metabolic pathways that lead to the formation of 


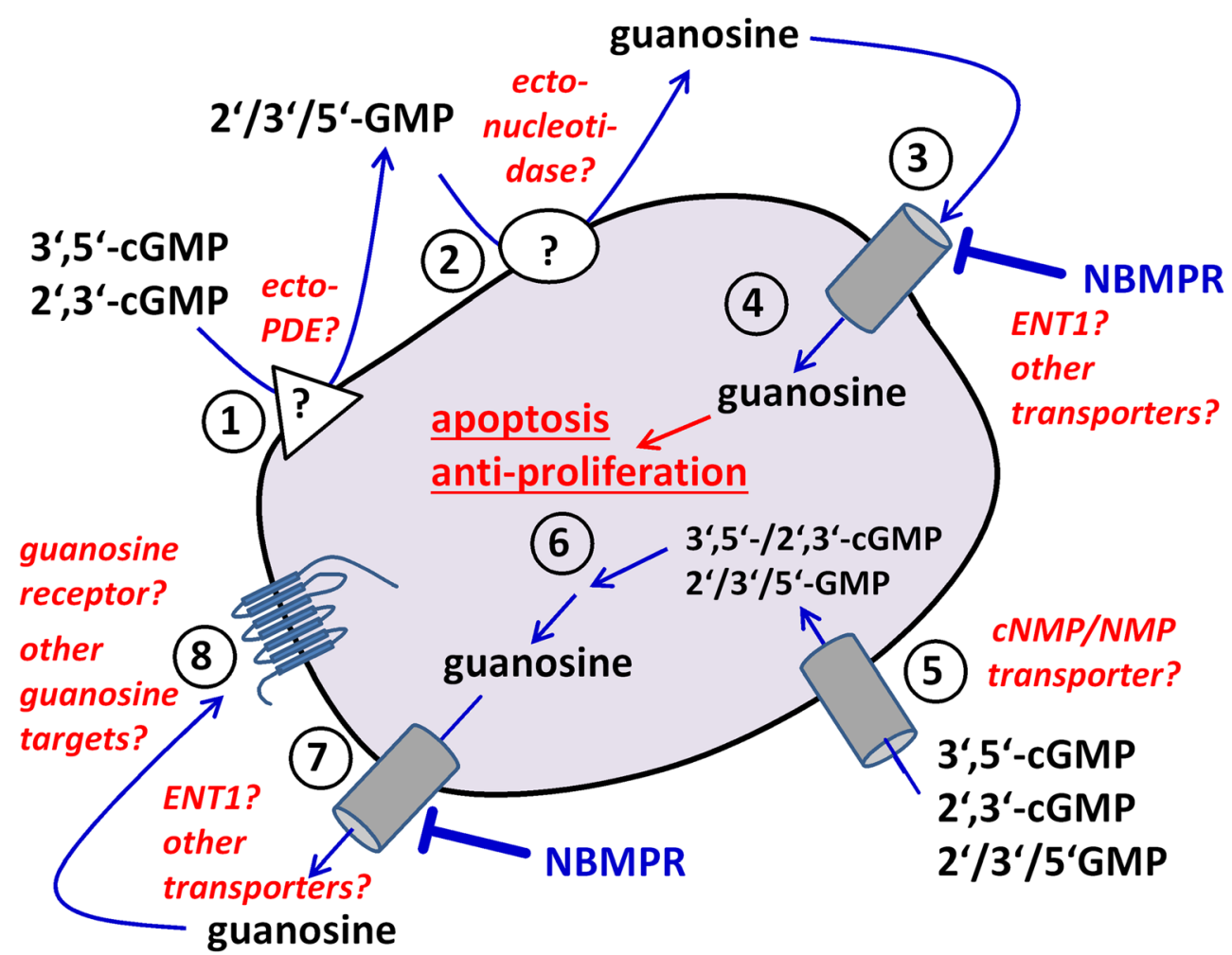

Fig. 9 Hypotheses explaining the NBMPR-sensitive apoptotic and antiproliferative effects of guanosine-derived compounds on HuT-78 cells. The numbers in the figure designate the following different factors/steps that might be involved: (1) 3',5'-cGMP and 2',3'-cGMP are hydrolyzed by a yet to be defined ecto-phosphodiesterase (ecto-PDE) on the cell surface. (2) The products of the ecto-PDE reaction, 5'-GMP (or 2'- or 3'-GMP), are metabolized by a still undefined ecto-nukleotidase, yielding guanosine. (3) Guanosine is taken up into the cell by an NBMPR-sensitive transporter (equilibrative nucleoside transporter

guanosine from cyclic guanine nucleotides have been described for 3',5'-cGMP (Albrecht et al. 2013) and, very recently, for 2',3'-cGMP (Jackson et al. 2019). A '2',3'-cGMP-guanosine pathway" (Jackson et al. 2019) has been suggested in analogy to the previously described ' 2 ', 3 '-cAMP-adenosine pathway" (Verrier et al. 2011; Jackson 2011).

Unexpectedly, the unselective ecto-phosphodiesterase inhibitor DPSPX did not eliminate the cytotoxic effects of $2^{\prime}, 3^{\prime}$ - or $3^{\prime}, 5^{\prime}$-cGMP, and the ecto-5'-nucleotidase inhibitor AMP-CP did not counteract the apoptotic and anti-proliferative action of $5^{\prime}$ GMP. It is unlikely that these inhibitors were inactivated by hydrolysis during the $72 \mathrm{~h}$ incubation time because we did not even observe an effect when fresh AMP-CP or DPSPX were re-added after $24 \mathrm{~h}$ and $48 \mathrm{~h}$. Thus, if guanosine was really formed from the guanosine-derived nucleotides in our experiments, the corresponding mechanism remains elusive.

The guanosine generated by guanosine nucleotide metabolism may be taken up by the cells through NBMPR-sensitive nucleoside transporters (Fig. 9, step 3) and then cause apoptotic and anti-proliferative effects by intracellular action (Fig. 9, step 4). It is well-known that extracellular nucleosides can be
ENT1?). (4) Intracellular guanosine causes the observed apoptotic and anti-proliferative effects. Alternative hypothesis, which is, however, considered less likely: (5) Uptake of $2^{\prime}, 3^{\prime}-13^{\prime}, 5^{\prime}$-cNMP and $5^{\prime}$-NMP (or $2^{\prime}$ - or $\left.3^{\prime}-\mathrm{GMP}\right)$ by yet to be defined membrane transporters. (6) Intracellular metabolism of $2^{\prime}, 3^{\prime}-13^{\prime}, 5^{\prime}$-cNMP and $5^{\prime}$-NMP (or 2'- or $3^{\prime}$ GMP) to yield guanosine. (7) Guanosine leaves the cell through an NBMPR-sensitive equilibrative nucleoside transporter (ENT1?) and (8) binds to a putative guanosine receptor (GPCR?) to cause apoptosis and growth inhibition

taken up by cells through specific transporters. As shown in Table 1, the various nucleoside transport processes can be divided in sodium-independent equilibrative (ENT) and sodium-dependent concentrative (CNT) processes. The ENT processes are bidirectional and comprise the es and the $e i$ process. The hENT1 molecule is basically responsible for es, while the hENT2 transporter shows $e i$ activity.

In our experiments with HuT-78 cells, $10 \mu \mathrm{M}$ of NBMPR, an inhibitor of the human equilibrative nucleoside transporters hENT1 $\left(\mathrm{IC}_{50}=0.4 \mathrm{nM}\right)$ and hENT2 $\left(\mathrm{IC}_{50}=2.8 \mu \mathrm{M}\right)$, completely eliminated the cytotoxic effects of guanosine and guanosine-derived nucleotides. Additional experiments indicated that even $1 \mu \mathrm{M}$ of NBMPR is already sufficient for the full protective effect. Concentration-effect curves with $100 \mu \mathrm{M}$ of guanosine alone or in combination with increasing concentrations of NBMPR resulted in NBMPR $\mathrm{IC}_{50}$ values of $25 \mathrm{nM}$ (apoptosis) and $28 \mathrm{nM}$ (proliferation). The Cheng-Prusoff equation (Cheng and Prusoff 1973) $\left(\mathrm{K}_{\mathrm{i}}=\mathrm{IC}_{50} /\left(1+[\mathrm{S}] / \mathrm{K}_{\mathrm{M}}\right)\right)$ was employed with $[\mathrm{S}]$ being the concentration of the substrate guanosine $(100 \mu \mathrm{M})$ and $K_{M}$ representing the guanosine $K_{M}$ value. Using the $K_{M}$ value of guanosine for hENT1 for the calculation 
(140 $\mu \mathrm{M}$, Table 1) yielded NBMPR $\mathrm{K}_{\mathrm{i}}$ values of $\sim 14.6 \mathrm{nM}$ (apoptosis) and of $16.3 \mathrm{nM}$ (proliferation). This is still $\sim 40$-fold higher than the literature NBMPR $\mathrm{K}_{\mathrm{d}}$ (high-affinity $\left[{ }^{3} \mathrm{H}\right]$ NBMPR binding) at hENT1 (0.38 nM; Ward et al. 2000), which may be due to the fact that we did not determine the direct effect of NBMPR on guanosine transporter activity but used an indirect downstream parameter (apoptosis or proliferation). By contrast, an alternative calculation using the guanosine affinity for hENT2 $(2700 \mu \mathrm{M}$, Table 1$)$ resulted in a $\mathrm{K}_{\mathrm{i}}$ of $24.1 \mathrm{nM}$ (apoptosis assays) or $27 \mathrm{nM}$ (proliferation experiments), which is more than 100 -fold lower than the NBMPR $\mathrm{IC}_{50}$ described for hENT2 in the literature $(2.8 \mu \mathrm{M}$; Ward et al. 2000). Unfortunately, no NBMPR $K_{d}$ value was reported by Ward et al (2000) for hENT2.

In summary, our results suggest involvement of hENT1 rather than $\mathrm{hENT2}$ in producing the cytotoxic effects of guanosine. It should be noted, however, that NBMPR does not only inhibit ENT1 but also the concentrative $\operatorname{csg}$ transport process that also accepts guanosine. The $c s g$ process (Table 1) was first functionally characterized in NB4 acute promyelocytic leukemia cells (Flanagan and Meckling-Gill 1997). Thus, our experiments currently cannot differentiate between ENT1 (es) and csg in HuT-78 cells. Future experiments should therefore strive for detecting the presence of hENT1 on the protein level in HuT-78 cells. By contrast, expression of the transporter for the csg process cannot be investigated because, to the best of our knowledge, its molecular identity is still elusive.

As far as we know, relevant transport of $2^{\prime}, 3^{\prime}$-cGMP, $3^{\prime}, 5^{\prime}$ cGMP, 2'-GMP, 3'-GMP, or 5'-GMP by the NBMPR-sensitive transport processes es or $c s g$ has not been reported so far. Thus, the cytoprotective effect of NBMPR in our experiments supports the notion that guanosine is formed as common endproduct of guanosine nucleotide metabolism and is in fact the active principle after intracellular uptake by guanosine transporters.

\section{Second hypothesis: guanosine is formed intracellularly and exported by an NBMPR-sensitive nucleoside transporter}

Alternatively, according to our second hypothesis, $2^{\prime}, 3^{\prime}-, 3^{\prime}, 5^{\prime}-$ cGMP, 2'-GMP, 3'-GMP and 5'-GMP could enter the cell via yet to be identified transporters (Fig. 9, step 5). For example, uptake of 3',5'-cGMP could be facilitated by the organic anion transporter OAT2 and, to a minor extent, by OAT1 or 3 (Henjakovic et al. 2015). The spectrum of guanine nucleotides transported by OAT2 seems to be rather broad as it also accepts 2'-deoxyguanosine, GMP, GDP, and GTP (Cropp et al. 2008). Guanosine may then be formed intracellularly (Fig. 9, step 6) and leave the cell through a (bidirectional!) NBMPRsensitive transporter, possibly hENT1 (Fig. 9, step 7). After that, guanosine may cause apoptosis by extracellular action, e.g. via putative guanosine receptors or other yet to be defined target sites (Fig. 9, step 8). Not much is known about guanosine receptors. Several years ago, a $\mathrm{G}$ protein-coupled guanosine receptor has been postulated in the rat brain on the basis of data from $\left[{ }^{3} \mathrm{H}\right]$ guanosine radioligand binding assays (Traversa et al. 2003, 2002), cAMP accumulation assays (Traversa et al. 2003), or europium-based $\mathrm{G} \alpha$-activation assays (Volpini et al. 2011). However, to the best of our knowledge, the molecular identity of this binding site is still elusive.

Since OATs are largely NBMPR insensitive, the second hypothesis would explain the inhibitory effect of NBMPR by a reduction of guanosine export from the cells. However, since this hypothesis assumes extracellular action of guanosine, it cannot explain why extracellularly applied guanosine acts in an NBMPR-sensitive way. Perhaps reality comprises a mixture of mechanisms from the first and the second hypothesis.

\section{Different effects of CGMP and CGMP-AM on IL-2 release and apoptosis/proliferation}

The ELISA data in Fig. 1 show that cGMP-AM does not affect IL-2 release, while 3',5'-cGMP has a pronounced inhibitory effect. By contrast, a weak and non-significant inhibitory effect of cGMP-AM on IL-2 release was visible in later experiments (Suppl. Fig. 3). It is noted, however, that the data in Suppl. Fig. 3 show large variability and the IL-2 release is only very low and not influenced by $\alpha \mathrm{CD} 3$. Thus, the results regarding the cGMP-AM effect on IL-2 production are rather inconclusive in Suppl. Fig. 3. By contrast, cGMP-AM had a clear pro-apoptotic and anti-proliferative effect (Suppl. Fig. 2), which was comparable with the cytotoxic effects of the other tested guanosine-related compounds.

We assume that the difference in cGMP-AM effect between IL2 ELISAs and apoptosis/proliferation experiments is due to the longer incubation time of $72 \mathrm{~h}$ in the apoptosis/ proliferation assays as compared to only $24 \mathrm{~h}$ in the ELISA experiments. Previous pilot experiments (data not shown) indicated that it took $72 \mathrm{~h}$ for $5^{\prime}$-GMP and guanosine to produce pronounced effects on apoptosis and proliferation. By contrast, IL-2 production by HuT-78 cells may follow a different time course. Moreover, intracellular delivery of cGMP from cGMP-AM may be more important during the first $24 \mathrm{~h}$ of incubation. By contrast, during longer incubation times, hydrolysis of cGMP-AM in the medium may produce large amounts of extracellular cGMP, which makes it difficult to discriminate between intracellular and extracellular actions of cGMP derived from cGMP-AM. The difference between the effects of cGMP and cGMP-AM and the underlying mechanisms should be investigated in more detail in future studies.

\section{(Patho)physiological roles of extracellular cGMP}

In our experiments, we have added extracellular cGMP to HuT-78 cell cultures. At first glance, this seems to be an odd 
way to investigate cGMP effects, as cGMP is widely recognized as an intracellular second messenger. However, (patho)physiological roles of extracellular cGMP have been demonstrated in the past. Suppl. Table 1 shows several examples of extracellular cGMP effects reported in the literature. Extracellular cGMP modulates natriuresis in the kidneys. It seems to interfere with the effect of various plateletactivating agents. Moreover, extracellular cGMP appears to act in the gastrointestinal tract, e.g. by modulating fluid absorption and secretion as well as visceral sensitivity. Numerous effects of extracellular cGMP have been reported in the CNS, mainly in animal models of hepatic hyperammonemic encephalopathy. The references in Suppl. Table 2 suggest that the effect of extracellular cGMP seems at least partly mediated by conversion to guanosine. However, Suppl. Tables 1 and 2 show mostly neuroprotective effects of extracellular cGMP and guanosine, while our results rather support apoptotic and anti-proliferative action of extracellular cGMP in HuT-78 cells. This difference suggests that extracellular cGMP exerts very distinct cell type-dependent effects.

\section{Nucleoside transporters and nucleoside-derived cytostatic drugs}

Nucleoside transporters are an important prerequisite for the activity of nucleoside-derived drugs, e.g., several anti-cancer agents. The NBMPR-sensitive transporter ENT1 mediates uptake of the cytostatic drugs gemcitabine, fludarabine, cladribine, and cytarabine (Table 1) (Pastor-Anglada et al. 2004). CEM lymphoblastic leukemia cells express ENT1 and are sensitive to gemcitabine (Mackey et al. 1998). However, in the presence of NBMPR, the $\mathrm{IC}_{50}$ of gemcitabine increased by more than a 100-fold (Mackey et al. 1998). Moreover, it has been recently reported that the imidazole nucleoside immunosuppressant mizoribine is taken up by L5178Y-R mouse lymphoma cells and metabolized to the corresponding monophosphate. The L5178Y-R cells express mRNA for both ENT1 and ENT2. Mizoribine uptake was inhibited by the unselective ENT1/ENT2 substrate adenosine but not by $0.1 \mu \mathrm{M}$ of the ENT1 inhibitor NBMPR (Oda et al. 2018).

Our results suggest that guanosine and/or guanosinerelated compounds could be an important addition to the cytostatic therapy of specific kinds of leukemia. The efficacy, however, may be highly dependent on the presence of the corresponding nucleoside transporters, e.g. ENT1 or csg. This has been demonstrated for several established cytostatic drugs. For example, CEM-ARA-C/8C cells are virtually resistant to gemcitabine because they are deficient of any kind of nucleoside transport (Mackey et al. 1998). Later, it has been reported that CEM-ARA-C/8C cells still express ENT1, but a glycine-to-arginine mutation in the ENT1 protein (G24R) results in a loss of nucleoside uptake activity (Zimmerman et al.
2009). Moreover, it has been proposed that immunohistochemical determination of hENT1 expression may be useful to predict gemcitabine or capecitabine resistance of breast cancer cells (Mackey et al. 2002).

Lack of nucleoside transporter expression in some cancers may cause resistance to nucleoside-derived cytostatic drugs. This may be the reason, why guanosine and guanosine-related compounds were practically ineffective in our experiments with ALL xenograft cells. In fact, it has been reported that es transporter expression in fresh leukemic lymphoblasts isolated from four different ALL patients showed considerable inter-individual variability that was reflected by very heterogeneous cytostatic effects of cytarabine (Gati et al. 1998). It should be noted, however, that no information about the exact type of ALL was provided by Gati et al. (1998). We hypothesize that the ALL clone used in our experiments may have shown a rather low expression of guanosine-transporting proteins. Thus, as previously recommended for breast cancer (Mackey et al. 2002), also in case of different kinds of leukemia, a pre-screening for nucleoside transporter expression may help to select patients responsive to therapy with nucleoside-derived cytostatics. In this regard, it should be noted that there may be other, NBMPR-insensitive, transport processes that are able to mediate guanosine uptake. For example, guanosine increased apoptosis of Jurkat (human T cell leukemia) cells in an NBMPR-insensitive way (Batiuk et al. 2001).

\section{Nucleoside transporters in PBMCs}

We can only speculate why guanine nucleotides and guanosine did not affect viability and proliferation of PBMCs in our experiments. Since we have cultured the PBMCs during our experiments for $72 \mathrm{~h}$ in the presence of $\alpha \mathrm{CD} 3$ - and $\alpha \mathrm{CD} 28$ antibody, we assume that proliferation of $\mathrm{T}$ cells was selectively stimulated and T cells were enriched in our culture. Very recently, it has been demonstrated that peripheral T cells show very high abundance of mRNA for ENT3 but only very low amounts of ENT1 or ENT2 mRNA (Wei et al. 2018). ENT3, however, is mainly expressed intracellularly in lysosomal and mitochondrial membranes (Govindarajan et al. 2009) and therefore unable to mediate uptake of extracellular nucleosides. By contrast, another publication reports hENT1 mRNA in PBMCs, but experiments with tritiated $\left[{ }^{3} \mathrm{H}\right]$ gemcitabine revealed that the concentrative nucleoside transporter hCNT1 contributed much more to $\left[{ }^{3} \mathrm{H}\right]$ gemcitabine uptake than hENT1 (Choi 2012). To the best of our knowledge, hCNT1 mainly accepts pyrimidine nucleosides as substrates and no guanosine transport by hCNT1 has been reported till now (Pastor-Anglada et al. 2004). Alternatively, PBMCs could take up guanosine by other transporters (e.g. hCNT2 or hCNT3) but may be resistant to the apoptotic effects of guanosine. 


\section{Conclusion and outlook}

We have identified apoptotic and anti-proliferative effects of guanosine and guanosine-related compounds in HuT78 human Sézary lymphoma cells. These effects seem to strongly depend on the activity of an NBMPR-sensitive nucleoside transporter, the identity of which is still elusive. Our concentration effect curves with NBMPR suggest that ENT2 is most likely not involved. We propose that guanosine and related compounds could serve as potential adjuvants for the treatment of various kinds of guanosine transporter-positive cancers, in addition to established cytostatic nucleoside analogues.

Future studies will have to clarify if HuT-78 cells take up guanosine via the es (ENT1) and/or the csg process. Moreover, other cancer cell lines should be tested for their guanosine sensitivity, and the data should be correlated with expression levels of ENT1 (e.g. as determined by $\left[{ }^{3} \mathrm{H}\right]$ NBMPR binding) or with the guanosine uptake capacity (e.g. uptake of $\left[{ }^{3} \mathrm{H}\right]$ guanosine). Moreover, it should be investigated whether extracellular effects of guanosine play a role in some cell lines, e.g. cytotoxicity mediated by adenosine receptors (Oliveira et al. 2017). Finally, the effect of guanosine should be investigated in mouse leukemia or lymphoma models since the guanosine-accepting es nucleoside transport process (probably caused by ENT1) was detected in murine lymphoma (S49) and leukemia (L1210) cancer cell lines (Mackey et al. 1998).

Acknowledgments We thank Ms. Silvia Jenni (Department of Pediatric Oncology, Children's Research Centre, University Children's Hospital Zürich, Zürich, Switzerland) for advice on culture and maintenance of the ALL xenograft cells.

Authors' contributions RS, ES, and SK conceived and designed research. SK and $\mathrm{OH}$ conducted experiments. ES and SK analyzed data. ES and SK wrote the manuscript. All authors read and approved the manuscript.

Funding Information Open Access funding provided by Projekt DEAL.

\section{Compliance with ethical standards}

Conflict of interest The authors declare that they have no conflict of interest.

Open Access This article is licensed under a Creative Commons Attribution 4.0 International License, which permits use, sharing, adaptation, distribution and reproduction in any medium or format, as long as you give appropriate credit to the original author(s) and the source, provide a link to the Creative Commons licence, and indicate if changes were made. The images or other third party material in this article are included in the article's Creative Commons licence, unless indicated otherwise in a credit line to the material. If material is not included in the article's Creative Commons licence and your intended use is not permitted by statutory regulation or exceeds the permitted use, you will need to obtain permission directly from the copyright holder. To view a copy of this licence, visit http://creativecommons.org/licenses/by/4.0/.

\section{References}

Albrecht P, Henke N, Tien ML, Issberner A, Bouchachia I, Maher P, Lewerenz J, Methner A (2013) Extracellular cyclic GMP and its derivatives GMP and guanosine protect from oxidative glutamate toxicity. Neurochem Int 62:610-619

Batiuk TD, Schnizlein-Bick C, Plotkin Z, Dagher PC (2001) Guanine nucleosides and Jurkat cell death: roles of ATP depletion and accumulation of deoxyribonucleotides. Am J Physiol Cell Physiol 281: C1776-C1784

Berrisch S, Ostermeyer J, Kaever V, Kälble S, Hilfiker-Kleiner D, Seifert R, Schneider EH (2017) cUMP hydrolysis by PDE3A. Naunyn Schmiedeberg's Arch Pharmacol 390:269-280

Cheng Y, Prusoff WH (1973) Relationship between the inhibition constant $\left(\mathrm{K}_{\mathrm{I}}\right)$ and the concentration of inhibitor which causes 50 per cent inhibition $\left(\mathrm{I}_{50}\right)$ of an enzymatic reaction. Biochem Pharmacol 22: 3099-3108

Choi MK (2012) Variability of gemcitabine accumulation and its relationship to expression of nucleoside transporters in peripheral blood mononuclear cells. Arch Pharm Res 35:921-927

Cropp CD, Komori T, Shima JE, Urban TJ, Yee SW, More SS, Giacomini KM (2008) Organic anion transporter 2 (SLC22A7) is a facilitative transporter of cGMP. Mol Pharmacol 73:1151-1158

Flanagan SA, Meckling-Gill KA (1997) Characterization of a novel $\mathrm{Na}^{+}-$ dependent, guanosine-specific, nitrobenzylthioinosine-sensitive transporter in acute promyelocytic leukemia cells. J Biol Chem 272:18026-18032

Frismantas V, Dobay MP, Rinaldi A, Tchinda J, Dunn SH, Kunz J, Richter-Pechanska P, Marovca B, Pail O, Jenni S, Diaz-Flores E, Chang BH, Brown TJ, Collins RH, Uhrig S, Balasubramanian GP, Bandapalli OR, Higi S, Eugster S, Voegeli P, Delorenzi M, Cario G, Loh ML, Schrappe M, Stanulla M, Kulozik AE, Muckenthaler MU, Saha V, Irving JA, Meisel R, Radimerski T, Von Stackelberg A, Eckert C, Tyner JW, Horvath P, Bornhauser BC, Bourquin JP (2017) Ex vivo drug response profiling detects recurrent sensitivity patterns in drug-resistant acute lymphoblastic leukemia. Blood 129(11):e26-e37. https://doi.org/10.1182/blood-2016-09-738070

Gati WP, Paterson AR, Belch AR, Chlumecky V, Larratt LM, Mant MJ, Turner AR (1998) Es nucleoside transporter content of acute leukemia cells: role in cell sensitivity to cytarabine (araC). Leuk Lymphoma 32:45-54

Godinho RO, Duarte T, Pacini ES (2015) New perspectives in signaling mediated by receptors coupled to stimulatory G protein: the emerging significance of cAMP efflux and extracellular cAMP-adenosine pathway. Front Pharmacol 6:58

Govindarajan R, Leung GP, Zhou M, Tse CM, Wang J, Unadkat JD (2009) Facilitated mitochondrial import of antiviral and anticancer nucleoside drugs by human equilibrative nucleoside transporter-3 Am J Physiol Gastrointest Liver Physiol 296:G910-G922

Gray JH, Owen RP, Giacomini KM (2004) The concentrative nucleoside transporter family, SLC28. Pflugers Arch 447:728-734

Henjakovic M, Hagos Y, Krick W, Burckhardt G, Burckhardt BC (2015) Human organic anion transporter 2 is distinct from organic anion transporters 1 and 3 with respect to transport function. Am J Physiol Renal Physiol 309:F843-F851

Jackson EK (2011) The 2',3'-cAMP-adenosine pathway. Am J Physiol Renal Physiol 301:F1160-F1167 
Jackson EK, Raghvendra DK (2004) The extracellular cyclic AMPadenosine pathway in renal physiology. Annu Rev Physiol 66: 571-599

Jackson EK, Mi Z, Janesko-Feldman K, Jackson TC, Kochanek PM (2019) 2',3'-cGMP exists in vivo and comprises a 2',3'-cGMP-guanosine pathway. Am J Phys Regul Integr Comp Phys 316:R783R790

Mackey JR, Mani RS, Selner M, Mowles D, Young JD, Belt JA, Crawford CR, Cass CE (1998) Functional nucleoside transporters are required for gemcitabine influx and manifestation of toxicity in cancer cell lines. Cancer Res 58:4349-4357

Mackey JR, Jennings LL, Clarke ML, Santos CL, Dabbagh L, Vsianska M, Koski SL, Coupland RW, Baldwin SA, Young JD, Cass CE (2002) Immunohistochemical variation of human equilibrative nucleoside transporter 1 protein in primary breast cancers. Clin Cancer Res 8:110-116

Oda K, Mori N, Okumi M, Furusawa M, Ishiguro M, Inoue K, Shuto S, Unagami K, Ishida H, Tanabe K, Murakami T (2018) Uptake and metabolism of mizoribine, an immunosuppressant, in L5178Y-R mouse lymphoma cells in vitro and peripheral blood mononuclear cells of rats and kidney transplant recipients in vivo. Drug Metab Pharmacokinet 33:232-239

Oliveira KA, Dal-Cim TA, Lopes FG, Nedel CB, Tasca CI (2017) Guanosine promotes cytotoxicity via adenosine receptors and induces apoptosis in temozolomide-treated A172 glioma cells. Purinergic Signal 13:305-318

Ostermeyer J, Golly F, Kaever V, Dove S, Seifert R, Schneider EH (2018) cUMP hydrolysis by PDE3B. Naunyn Schmiedeberg's Arch Pharmacol 391:891-905

Pastor-Anglada M, Molina-Arcas M, Casado FJ, Bellosillo B, Colomer D, Gil J (2004) Nucleoside transporters in chronic lymphocytic leukaemia. Leukemia 18:385-393

Saute JA, da Silveira LE, Soares FA, Martini LH, Souza DO, Ganzella M (2006) Amnesic effect of GMP depends on its conversion to guanosine. Neurobiol Learn Mem 85:206-212

Scharrenbroich J, Kaever V, Dove S, Seifert R, Schneider EH (2019) Hydrolysis of the non-canonical cyclic nucleotide cUMP by PDE9A: kinetics and binding mode. Naunyn Schmiedeberg's Arch Pharmacol 392:199-208

Schneider E, Wolter S, Dittmar F, Gonzalo F, Seifert R (2015) Differentiation between first and second messenger effects of cGMP. BMC Pharmacol Toxicol 16(Suppl 1):A84

Seifert R, Schneider EH, Bähre H (2015) From canonical to noncanonical cyclic nucleotides as second messengers: pharmacological implications. Pharmacol Ther 148:154-184
Soares FA, Schmidt AP, Farina M, Frizzo ME, Tavares RG, Portela LV, Lara DR, Souza DO (2004) Anticonvulsant effect of GMP depends on its conversion to guanosine. Brain Res 1005:182-186

Traversa U, Bombi G, Di Iorio P, Ciccarelli R, Werstiuk ES, Rathbone MP (2002) Specific $\left[{ }^{3} \mathrm{H}\right]$-guanosine binding sites in rat brain membranes. Br J Pharmacol 135:969-976

Traversa U, Bombi G, Camaioni E, Macchiarulo A, Costantino G, Palmieri C, Caciagli F, Pellicciari R (2003) Rat brain guanosine binding site. Biological studies and pseudo-receptor construction. Bioorg Med Chem 11:5417-5425

Verrier JD, Exo JL, Jackson TC, Ren J, Gillespie DG, Dubey RK, Kochanek PM, Jackson EK (2011) Expression of the 2',3'-cAMPadenosine pathway in astrocytes and microglia. J Neurochem 118: 979-987

Volpini R, Marucci G, Buccioni M, Dal Ben D, Lambertucci C, Lammi C, Mishra RC, Thomas A, Cristalli G (2011) Evidence for the existence of a specific $\mathrm{g}$ protein-coupled receptor activated by guanosine. ChemMedChem 6:1074-1080

Ward JL, Sherali A, Mo ZP, Tse CM (2000) Kinetic and pharmacological properties of cloned human equilibrative nucleoside transporters, ENT1 and ENT2, stably expressed in nucleoside transporterdeficient PK15 cells. Ent2 exhibits a low affinity for guanosine and cytidine but a high affinity for inosine. J Biol Chem 275: 8375-8381

Wei CW, Lee CY, Lee DJ, Chu CF, Wang JC, Wang TC, Jane WN, Chang ZF, Leu CM, Dzhagalov IL, Hsu CL (2018) Equilibrative nucleoside transporter 3 regulates T cell homeostasis by coordinating lysosomal function with nucleoside availability. Cell Rep 23:2330-2341

Yilmaz MS, Coskun C, Suzer O, Yalcin M, Mutlu D, Savci V (2008) Hypotensive effects of intravenously administered uridine and cytidine in conscious rats: involvement of adenosine receptors. Eur J Pharmacol 584:125-136

Young JD, Yao SY, Sun L, Cass CE, Baldwin SA (2008) Human equilibrative nucleoside transporter (ENT) family of nucleoside and nucleobase transporter proteins. Xenobiotica 38:995-1021

Zimmerman EI, Huang M, Leisewitz AV, Wang Y, Yang J, Graves LM (2009) Identification of a novel point mutation in ENT1 that confers resistance to Ara-C in human T cell leukemia CCRF-CEM cells. FEBS Lett 583:425-429

Publisher's note Springer Nature remains neutral with regard to jurisdictional claims in published maps and institutional affiliations. 